\title{
ALGUNAS CUESTIONES SOBRE LA SOBERANÍA EN EL PROCESO DE INTEGRACIÓN EUROPEA
}

\author{
NOEMI GARCÍA GESTOSO \\ Profesora de Derecho Constitucional \\ Universidad de Vigo
}




\section{SUMARIO}

I. INTRODUCCIÓN: LOS CARACTERES DE LA SOBERANÍA DEL ESTADO ANTE EL PROCESO DE INTEGRACIÓN EUROPEA. II. SOBERANIA E INTEGRACIÓN. III. «FORMA ESTATAL", "CONSTITUCIÓN" Y "REFORMA CONSTITUCIONAL" EN EL PROCESO INTEGRADOR EUROPEO. IV. LOS PRINCIPIOS CONSTITUCIONALES Y EL FUTURO DE LA UNIÓN EUROPEA. 


\title{
ALGUNAS CUESTIONES SOBRE LA SOBERANÍA EN EL PROCESO DE INTEGRACIÓN EUROPEA
}

POR

\author{
NOEMI GARCÍA GESTOSO \\ Profesora de Derecho Constitucional \\ Universidad de Vigo
}

I. INTRODUCCIÓN: LOS CARACTERES DE LA SOBERANIAA DEL ESTADO ANTE EL PROCESO DE INTEGRACIÓN EUROPEA

Los Estados Constitucionales europeos están inmersos en un gigantesco proceso de cambio por su participación en el fenómeno integrador europeo. Frente a las añejas relaciones interestatales, entabladas desde el respeto del principio de soberanía estatal, surgen en el seno de la Unión Europea otras distintas, que se basan en la traslación de competencias de los Estados miembros a las instituciones comunes que han creado y que implica una merma de la soberanía estatal, entendida como capacidad de decisión última y suprema, ya que el ejercicio efectivo de esas competencias y poderes por el nuevo ente se manifiesta sustancialmente en la producción de normas jurídicas que inciden directamente en la esfera jurídica de los nacionales de todos los Estados participantes rompiendo la impenetrabilidad jurídica tradicional del Estado'. Sucede entonces que la existencia y desa-

1 Resaltando la limitación que sufre el Estado comunitario en el ámbito normativo, cfr., por todos, Pérez Calvo, A., "La dimensión comunitaria del Estado en la Europa occidental», Civitas Europa, n. 1, 1998, pág. 20; Ídem, "La nueva dimen- 
rrollo de la Unión Europea cuestiona la vigencia de los rasgos básicos inescindibles del concepto verdadero, moderno y técnico de Constitución, y por ello debe analizarse desde la Teoría Constitucional. En este trabajo se pretende analizar la Unión Europea desde los supuestos políticos y jurídicos que están en su origen, empezando por la soberanía estatal de la que se nutre, con el fin de determinar hasta qué punto el proceso de integración le afecta, o, desde otro ángulo, dilucidar cuál es el grado de estatalidad alcanzado en la nueva entidad supranacional en detrimento de los Estados partícipantes, o, por último, si estamos en una época en que todas estas realidades y conceptos están llegando a su fin.

Lógicamente, la limitación propia de un trabajo de este tipo, hace que su objetivo sea esbozar las líneas generales de los principales problemas que se plantean desde la óptica constitucional en las relaciones entre los Estados miembros y la Unión Europea. Por otra parte, somos conscientes del carácter esencialmente dinámico que presenta el proceso de integración europea, que, a su vez, se ve influido por los cambios que se están produciendo en el orbe mundial, que afectan a los principios basilares sobre los que se ha erigido el Derecho internacional y el Derecho interno estatal, especialmente por el fenómeno de globalización económica ${ }^{2}$. Ello origina que sus conclusiones sean necesariamente provisionales, ya que resulta difícil vislumbrar los nuevos principios y conceptos sobre los que se puede estructurar la convivencia política y social ordenada racionalmente por el Derecho en el futuro. Así las cosas, entendemos que se ha de abordar la problemática de las relaciones entre el ordenamiento jurídico comunitario y los nacionales partiendo desde las preocupaciones y planteamientos que hicieron nacer el Estado Constitucional, prestando especial atención al concepto, significado y funciones de la Constitución y de la legitimación del poder a la que responde, con

sión comunitaria del Estado moderno", en Garcia HerRera, M.A. (dir.) y otros, El constitucionalismo en la crisis del Estado social, Bilbao, 1997, pág. 515; Ídem, "Las transformaciones estructurales del Estado-Nación en la Europa comunitarian, Revista de Estudios Políticos, n. ${ }^{\circ} 99,1998$, pág. 13.

2 Cfr., por todos, DE VEGA, P., «Mundialización y Derecho constitucional: la crisis del principio democrático en el constitucionalismo actual", Revista de Estudios Políticos, n. ${ }^{\circ} 100,1988$, págs. 13-55. Vid, también, ARenAL MoYúa, C., "El nuevo escenario mundial y la teoría de las relaciones internacionales", en PÉrEz GoNZÁLEZ, M.; SÁNCHEZ IgLESIAS, L. I., y otros (Comisión organizadora), Hacia un nuevo orden internacional y europeo, Libro homenaje al profesor M. Diez de Velasco, Madrid, 1993, págs. 79-99. 
la finalidad de dilucidar qué resulta irrenunciable en el proceso integrador en curso.

El Estado Constitucional constituye, como se sabe, una transformación del Estado moderno que surge, indisolublemente ligado a la aparición y consolidación del concepto de soberanía, en los siglos $X V$ y XVI en el continente europeo, y que supone una nueva forma de estructurar la convivencia política y social ${ }^{3}$. Elemento fundamental del Estado moderno es la soberanía, de modo que se caracterizará por la existencia de un único y supremo centro de poder sobre una población y territorios determinados que ostenta el monopolio de la prerrogativa legislativa ${ }^{4}$. La supremacía e indivisibilidad del poder estatal son el presupuesto necesario para construir un sistema jurídico como conjunto completo y coherente ${ }^{5}$. De este modo, la soberanía fun-

3 Como señala Heller, H., Teoría del Estado, 1.? ed., 13.a reimpr., Méjico, 1990 , pág. 43, la forma estatal moderna reviste una peculiaridad individual que lo diferencia de las estructuras de otros tiempos, ya que responden a unos mismos rasgos configuradores que les definen como Estados, con independencia de sus elementos diferenciales. En el mismo sentido, vid. Crossman, R. H. S., Biografía del Estado Moderno, Méjico, 1982, págs. 19-23; MARAVALL, J. A., Estado moderno y mentalidad social (s. XV a XVII), Madrid, 1972; LuCAS Verdú, P., Curso de Derecho Politico, vol. II: La crisis del Estado en la actualidad. Federalismo y estado federal. La teoría de la Constitución en el marco del Derecho político., 3." ed., 2. Madrid, 1986, pág. 42.

4 Sobre la soberanía como rasgo común y fundamental del Estado, cfr. JELLINEK, G., Teoría general del Estado, Buenos Aires, 1978, págs. 242 y ss.; HeLLeR, H., La Soberanía. Contribución a la Teoria del Derecho estatal y del Derecho internacional, Méjico, 1965, págs. 122 y ss.; KRIELE, M., Introducción a la Teoría del Estado. Fundamentos históricos de la legitimidad del Estado Constitucional Democrático, Buenos Aires, 1980, pág. 3. Por otro lado, para JeLLINEK, G., Teoría general..., op. cit., págs. 295 y ss., existe Estado cuando se dan estos tres elementos constitutivos: territorio, población y poder estatal, relacionados recíprocamente en una estructura determinada. Desde entonces, es común entre la doctrina acercarse a la definición del Estado descriptivamente, partiendo del consenso en torno a la necesidad de tales elementos.

5 Desde estos orígenes, la soberanía se manifiesta como poder por esencia estatal, propio de la unidad y omnipotencia del Estado que surge, ya que trata de responder a la necesidad de encontrar una nueva forma de ordenación de la totalidad de la vida pública, por lo que conllevará una manera distinta de entender el poder que se concreta en ciertas notas específicas que le dan su sustancia y sirven para definirlo. Cfr., por todos, Ramiro RıCo, N., "La soberanía", en El animal ladino y otros estudios políticos, Madrid, 1980, pág. 124. Históricamente, será a partir del ocaso de la Edad Media cuando se asientan los presupuestos que propician el reemplazo de las estructuras tradicionales por los Estados soberanos. Sobre esta época y sus transformaciones, vid., entre otros, ULLMANN, W., Principios de gobierno y política en la Edad Media, Madrid, 1971; GARCía PeLAYo, M., "Hacia 
damenta el poder público sobre la base de su unidad pasándose a un sistema de dominación general y efectiva. La soberanía caracteriza un centro de poder que se impone al resto y que monopoliza todos los derechos y facultades, consiguiendo ligar todas las acciones de los gobernantes a un único origen, el poder soberano estatal. El poder público de la comunidad política se objetiviza y configura como supremo y sobre el mismo se asienta el Estado nacional con sus instrumentos propios. Desde entonces se considera que la nota esencial del Estado es la existencia de una comunidad con un poder originario, supremo y medios coercitivos suficientes, que domina sobre sus miembros y territorio conforme un poder que le es inmanente ${ }^{6}$. Se en-

el surgimiento del Estado moderno", en el vol. Idea de la Política y otros escritos, Madrid, 1983, págs. 107-133. Entre estos presupuestos está la soberanía que, como señala JELLINEK, G., Teoría general..., op. cit., págs. 331 y ss., nace como un concepto político y polémico en el contexto de las luchas constantes entre poderes que reclamaban entonces la supremacía. Su primera conceptualización corresponde a J. BoDIN en su obra Los seis libros de la República, publicada en 1576. J. BoDIN se enfrenta en la Francia del s. XVI a la primera gran crisis de un Estado Moderno que ya existe y que considera esencial para garantizar la paz, lo que ha de hacerse a través del reforzamiento de su poder. Al proceder a su fundamentación y caracterización acuñará el concepto de soberania, con el carácter y sentido que se concede al término en Teoría política y jurídicamente, definiéndola como uel poder absoluto $y$ perpetuo de una República», entendiendo República como Estado, caracterizado por ser perpetuo, absoluto, único e indivisible, e inalienable. Al buscar su concreción práctica, colige que es en el derecho a legislar sin necesidad del consentimiento de nadie donde está la esencia de la soberanía. De este modo, soberano será aquél que detenta originariamente la prerrogativa legislativa, esto es, aquél cuya voluntad se impone a todos y que no está sujeto, ni debe sus facultades a ninguna otra autoridad. Cfr. BodıN, J., Los seis libros de la República, Madrid, 1985, en particular págs. 47-84.

6 Cfr. JellineK, G., Teoría general..., op. cit., pág. 368, indicando que "donde haya una comunidad con un poder originario y medios coercitivos para dominar sobre sus miembros y su territorio, conforme a un orden que le es propio, allí existe un Estado", y HeLLER, H., Teoría del..., op. cit., pág. 151, quien define al Estado como una unidad de poder independiente. Desde esta perspectiva se concibe la soberanía estatal fundamentalmente como facultad de imposición "legibus solutus". Pero, también es cierto que esta soberanía política o de hecho encuentra su modo usual de ejercicio a través del Derecho y de la ley, de tal modo que la soberanía que sustenta al Estado es la que hace que éste se presente esencialmente como jurídico. En este sentido, como observa Heller, en primer lugar, la unidad del poder público, se refleja en la exclusividad en manos del Estado del Derecho. A partir de entonces, el Estado moderno se caracterizará por detentar el monopolio en la creación de normas jurídicas, desarrollándose sobre esta base el Derecho como realidad unitaria, jerárquica y verticalmente ordenada en torno a una fuente única de acción, que se impone a todos merced a la existencia de un poder coactivo único que da eficacia jurídica a sus decisiones. 
tiende que el Estado dispone de capacidad para la creación de sus normas con una legitimidad propia, independiente de cualesquiera otros poderes y se crea el Derecho en sentido moderno. De este modo, en el ámbito interno la soberanía significa supremacía y exclusividad, mientras que, en su vertiente externa, se proyecta como independencia sobre la base de la igualdad soberana de los Estados que participan en las relaciones en el marco de la comunidad internacional a través de la conclusión de Tratados Internacionales que suponen una recíproca autolimitación de su soberanía consentida libérrimamente?

Este alcance y contenido de la soberanía continúan siendo válidos en el Derecho Público actual, si bien despojados del primigenio sentido absolutista por la irrupción y triunfo de las ideas constitucionalistas, que transfieren su titularidad del monarca al Pueblo. Tal cambio conlleva consecuencias de primer orden en la idea y estructura del poder estatal, las cuales sólo pueden ser comprendidas analizando el surgimiento del Estado Constitucional y su evolución, articulándose a través de la noción de Poder Constituyente que se corresponde con el principio de soberanía popular, soporte del Estado constitucional contemporáneo ${ }^{8}$. En efecto, se entiende que únicamente reside en el pue-

7 Cfr., entre otros, Lucas Verdú, P., Curso de..., vol. II, op. cit., pág. 117; SáNChez Agesta, L., Principios de Teoría Política, 6. ${ }^{\circ}$ ed., Madrid, 1979, pág. 474; Pérez Serrano, N., Tratado de Derecho Político, 2." ed., Madrid, 1984, pág. 128. Sobre su vertiente externa, cfr. JELLINEK, G., Teoría general..., op. cit., pág. 281, para quién "la distinción esencial entre el Derecho Internacional y el Derecho del Estado particular, radica en que en aquél no existe regulada ninguna relación entre superior e inferior, sino que se trata de relaciones de coordinación, pues las autoridades que ponen el Derecho internacional y los sujetos que están obligados a su cumplimiento son los mismos, a saber: los Estados".

8 En la evolución liberal y democrática del substrato ideológico del fenómeno estatal, se cambiarán tanto el titular como los límites de actuación de su poder a través de la teoría de la soberanía popular que considera al pueblo el titular de la sanción última del Derecho. En suma, se pasa a la soberanía del Poder Constituyente del Pueblo o, en otras palabras, al Estado de los ciudadanos, originando el nacimiento de las Constituciones y del constitucionalismo en el sentido auténtico, técnico y moderno que tales conceptos siguen revistiendo hoy. Cfr. en este sentido, por todos, DE VEGA, P., "Constitución y Democracia», en la ob. Col. La Constitución Española de 1978 y el Estatuto de Autonomía del País Vasco, Oñati, 1983, págs. 66-73; Ídem, La reforma constitucional y la problemática del Poder Constituyente, Madrid, 1985, págs. 15-24; Ídem, "En torno al concepto político de Constitución", en García Herrera, M. A. (dir.) y otros, El constitucionalismo en la crisis del Estado social, Bilbao, 1997, págs. 704-719; Ídem, "Mundialización...", cit., pág. 25, resaltando que la idea de soberanía, como nota más característica del Estado moderno, se encuentra uen la circunstancia de que se trata de un poder que tie- 
blo la capacidad de decidir libremente las bases de organización de su convivencia política y social, lo que hace mediante la aprobación de su Constitución, que enmarca mediante normas jurídicas toda actuación sucesiva del poder público, que resulta, de esta guisa, una voluntad siempre subordinada a lo decidido por el soberano. Se produce la legitimación democrática ${ }^{9}$ del poder en su origen y se ponen en pie los mecanismos jurídicos precisos para que todo ejercicio de poder, desde entonces actuaciones de poderes constituidos, no puedan ir en contra de la voluntad soberana manifestada en la Constitución ${ }^{10}$.

ne en el pueblo su última y definitiva justificación". En el mismo sentido, cfr. BEAUD, O., La puissance de l'État, Paris, 1994, págs. 203 y ss.

9 En esta tesitura, el principio y concepto de soberanía sigue desempeñando un papel determinante como criterio de la existencia de un Estado, Estado democrático, en el que la pregunta de en virtud de qué título se ejerce y se obedece de manera espontánea el poder, esto es, su legitimidad, encuentra su respuesta en el marco de la moderna Teoría de la Constitución que atribuye la titularidad del poder constituyente al pueblo. La legitimidad democrática es ante todo una legitimidad de origen que se manifiesta a través de la aprobación de la Cons. titución por el pueblo. En este sentido, constituye el presupuesto y justificación última de toda la legalidad al hacer posible la existencia de un sistema jurídico y de un poder que se ejerce conforme a sus reglas. Como dice Ferrero, G., El Poder. Los genios invisibles de la ciudad (Introducción, traducción y notas de Eloy García), 2.* ed. Revisada, Madrid, 1998, pág. 187, «un gobierno es legítimo cuando el poder se atribuye y se ejercita según principios y reglas aceptadas sin discusión por aquéllos que deben obedecer". Si bien los principios de legitimidad política han sido diversos a lo largo de la historia - principio electivo, hereditario, artistomonárquico y democrático-, en el mundo europeo contemporáneo y en la mayor parte de las naciones civilizadas actuales, el principio fundamental es hoy el principio de legitimidad democrático que encuentra su exponente en la Teoría de la Constitución correctamente entendida. En este sentido, el principio de legitimidad democrático considera legítimo el poder que deriva de la autoridad del Pueblo y por ello obtiene su consentimiento y va a ser una legitimidad racional, fundada sobre la legalidad. Se trata de una legitimidad sustancial basada en la prevalencia de la Constitución como Norma fundadora del poder público. Cfr. Ferrero, G., El Poder..., op. cit., passim; Bоввıо, N., "Sobre el principio de legitimidad", en Boввıо, N., Contribución a la Teoría del Derecho, Valencia, 1980, págs. 307-316.

10 Entendimiento de la Constitución como auténtica norma juridica cuya aprobación corresponde al Pueblo como conjunto de ciudadanos y que ocupa el lugar jerárquicamente superior de todo el sistema, protegiéndose mediante la rigidez constitucional y un sistema de justicia constitucional. No obstante, para llegar a ser reales tales axiomas en el Continente europeo, habrá que esperar al fin de la Segunda Guerra Mundial, produciéndose desde la Revolución francesa una evolución marcada por la lucha entre el principio de legitimidad monárquico y el democrático. Cfr. en torno a esta evolución y las consecuencias que tuvo la noción de soberanía nacional proclamada por E.-J. SIEYĖS en el contexto del régimen representativo, y los equívocos y ambigüedades que experimentó el constitucionalis- 
Se hace de este modo cierta la afirmación de que en el Estado constitucional en funcionamiento no hay soberano, pues no existen poderes ilimitados. En último caso, lo que existe es la soberanía de la Constitución ${ }^{11}$. El anhelo de limitar el poder por el Derecho deviene realidad.

\section{SOBERANÍA E INTEGRACIÓN}

Sin embargo, desde que surge el concepto y manifestaciones do la soberanía estatal aparecen críticas a su significado desde diversc; puntos de vista ${ }^{12}$, interesándonos especialmente las que se suscita. p por la aparición de las Comunidades Europeas. En efecto, como quiera que la integración europea se caracteriza por la transferencia de atribuciones de los Estados a un ente nuevo, lo que implica forzosamente una merma en la soberanía estatal, especialmente en rela-

mo en nuestro Continente desde su nacimiento hasta bien entrado el s. $X X$, DE VEGA, P., La reforma constitucional y..., op. cit., págs. 38-48; RourA GómEZ, S., La defensa de la Constitución en la historia constitucional española, Madrid, 1998, págs. 108-133. Es en el momento en que en la praxis se produce realmente el cambio en la titularidad de la soberania, trasvasándola al Pueblo en su conjunto, lo que determinará la entrada en la democracia. $Y$ al aunarse con el principio representativo, correctamente entendido, y con la idea de limitación de poder del gobernante, se darán todos los elementos necesarios para propiciar la aparición de la noción del Poder Constituyente tal y como se conoce en la actualidad, así como el de Constitución en su doble sentido formal y material. Cfr., en este sentido, por todos, RuIPÉREz, J., La "Constitución Europea" y la teoría del Poder Constituyente. Algunas reflexiones críticas desde el Derecho Político, Madrid, 2000, págs. 9093, págs. 100-133.

11 Cfr. KRIELE, M., Introducción a la..., op. cit., págs. 315-316. En el mismo sentido, cfr. KeLSEN, H., Teoría general del Estado, 15. ${ }^{\circledR}$ ed., Méjico, 1979, págs. 141 y ss.; Ídem, Esencia y valor de la democracia, 2.. ed., Barcelona, 1977, págs. 150152, indicando que en el Estado Constitucional el soberano es el Derecho, enmarcado en la Constitución, considerada, a partir de entonces, el eje de referencia y el parámetro de validez de la totalidad del sistema.

12 Cfr. en este sentido, por todos, la exposición que de estas diversas corrientes y sus autores más relevantes realiza Pérez Serrano, N., Tratado de Derecho..., op. cit., págs. 147-169. Entre tales teorías y críticas interesan especialmente las planteadas sobre la indivisibilidad o no de la soberanía con el fin de dar acomodo al Estado federal que surge desde el siglo XVIII en Norteamérica, por resurgir actualmente aplicadas a la Unión Europea. Cfr., al respecto, RUIPÉREZ, J., "Principio democrático y federalismo. El Poder Constituyente como único soberano posible en el Estado políticamente descentralizado", Anuario da Facultade de Dereito da Universidade da Coruña, n. ${ }^{\circ} 3,1999$, págs. 517-557. 
ción con el monopolio del Derecho interno, nada tiene de extraño que se cuestione el alcance y significado de la soberanía estatal en ese nuevo marco. En este sentido, la doctrina jurídica señala que el proyecto europeo en curso provoca una notable relativización de esta noción en su sentido tradicional y también, desde la óptica comunitaria, se hace referencia a tales cambios. Todo ello demuestra que el concepto de soberania estatal con el sentido que ha llegado hasta nuestros tiempos, necesariamente va a tener que ser adaptado para dar respuesta a la participación de los Estados en las Comunidades Europeas.

En realidad, estamos inmersos en un proceso de evolución del significado de la soberanía que parte desde el fin de la Segunda Guerra Mundial, en el que se modula su alcance para adaptarlo a las nuevas necesidades de la cooperación interestal que se dirigen a la formación de entidades supranacionales a las que se les transfiere el ejercicio efectivo de competencias hasta entonces ejercidas por los Estados aisladamente, como sucede con la creación de las Comunidades Europeas. En un principio, se partirá de la concepción doctrinal de la soberanía propia del Derecho Internacional moderno, que entiende que la conclusión de un Tratado Internacional por un Estado no constituye en ningún caso un abandono de su soberanía, sino una restricción estatal voluntaria de parte del ejercicio de los derechos que la integran, aplicádose el mismo enfoque a la decisión de un Estado de adherirse a una Organización Internacional a la que se le confierea el poder de adoptar normas que vinculan a los Estados participantes e incluso directamente a sus nacionales.

Pero sucede que los Tratados comunitarios imponen mayores restricciones a los Estados que cualquier otro Tratado y originan profundos problemas constitucionales y transformaciones en los Estados participantes, especialmente en la base de los sistemas constitucionales estatales europeos y de toda la Teoría Constitucional moderna, forjada sobre la soberanía popular a través de la cual se pueden reconducir, en última instancia, las distintas manifestaciones de poder político al pueblo como soberano. Así, las instituciones actúan en nombre del pueblo y son legitimadas directa o indirectamente por el electorado. Por el contrario, resulta difícil aplicar este mismo proceso al ejercicio de poder político que realizan instituciones supranacionales que no actúan en nombre de un pueblo singular, que no están o sólo remotamente legitimadas democráticamente, y que presentan dificultades de control.

En esta tesitura se analiza la integración europea sobre el concepto de soberanía, planteándose distintas teorías sobre su divisibili- 
dad. Por una parte, se estima que la soberanía debe concebirse como un conjunto de poderes que pueden ser divididos entre distintos niveles de gobierno, y que, por lo tanto, cabe una transferencia parcial de soberanía a favor de las Comunidades, cuyo resultado será la limitación de la soberanía estatal en áreas particulares y de modo irreversible, coligiéndose que en el momento actual la soberanía está dividida entre la Comunidad y los Estados miembros ${ }^{13}$. Por otro lado, se plantea abandonar el concepto de soberanía al analizar la integración por considerar que en la relación existente entre los Estados y la Unión ninguno ostenta la autoridad última, y que, por lo tanto, tal concepto ha perdido su valor explicatorio para aprehender las relaciones entre los distintos niveles de gobierno existentes, debiendo sustituirse por el principio de competencia ${ }^{14}$.

No obstante, el carácter concluso y resistente de la soberanía estatal sigue desplegando sus efectos en este nuevo entorno, y dificulta las relaciones entre los Estados miembros y la Unión Europea. La razón se encuentra en que la soberanía sigue siendo una categoría dotada de un valor singular para fundamentar el poder público en el marco del Estado Constitucional contemporáneo, mediante la noción del poder constituyente del Pueblo, y esto es así también en las rela-

13 Cfr. en esta línea, Pescatore, P., Le droit de l'intégration, Leiden, 1972, págs. 34 y ss.; Ídem, "L'apport du droit communautaire au droit international public", Cahiers de Droit Européen, 1970, págs. 501-525, en particular, págs. 502507. Louls, J. V., L'ordre juridique communautaire, 6." ed., Luxembourg, 1993; págs. 13-19; BoRCHARDT, K.-D., The ABC of Community Law, 3. éd., Luxembourg, 1991, págs. 9 y ss.; TEMPLE LANG, J., "Le projet de traité instituant I'Union européenne et les États membres: I'Irlande", en L'Europe de demain, Bruxelles, 1985, págs. 264-266.

14 Vid. en esta línea, FroweIN, J.A., "Das Maastricht-Urteil und die grenzen der Verfassungsgerichtsbarkeit", Zeitschrift für ausländisches Öffentliches Recht und Völkerrecht, n. ${ }^{\circ} 54,1994$, págs. 1 y ss.; ÖHLINGER, T., "Verfassungsfragen zwischen Brüssel und Wien", Révue Européen de Droit Public, vol, 5, n. ${ }^{\circ}$, 1993, págs. 143-173; Mc CORMICK, N., "Beyond the Sovereign State", The Modern Law Review, vol. 56, n. ${ }^{\circ} 1,1993$, pp 1-18. En sentido similar se propone la idea de una soberanía funcional para explicar el proceso de integración. Vid., en este sentido y por todos, PÉREZ Vera, E., "La ciudadanía europea en el Tratado de Maastricht", en Pérez González, M., SÁNChez Iglesias, L.I. y otros (Comisión organizadora), Hacia un nuevo orden internacional $y$ europeo, Libro homenaje al Profesor M. Díez de Velasco, Madrid, 1993, págs. 1123-1147; LaviLla AlsinA, L., "Las relaciones entre los ordenamientos nacional y comunitario", en La Constitución española en el ordenamiento comunitario europeo, XVI Jornadas de Estudio organizadas por la Dirección General del Servicio Jurídico del Estado, vol. I, Madrid, 1995, págs. 23-40. 
ciones entre los Estados constitucionales y la Unión Europea ${ }^{15}$. La razón se encuentra en que el proceso integrador se basa en las cláusulas de integración contenidas en las Constituciones de los Estados miembros ${ }^{16}$, que constituyen el fundamento constitucional que permite la transferencia y correlativo ejercicio de determinadas competencias al nuevo ente creado. Las Constituciones nacionales amparan dentro de unos límites irrenunciables el ejercicio efectivo de estas competencias y sus consecuencias. No se puede olvidar que ha sido el Poder Constituyente del Pueblo de cada uno de los Estados el que como soberano ha juridificado el sistema mediante su Constitución. Por lo tanto, no se puede admitir una quiebra ilimitada en este principio por el fenómeno comunitario sin poner en entredicho el principio de soberanía popular democrático.

15 Ahora bien, las primeras posturas comentadas terminan planteando que se han transferido un número limitado de derechos de soberanía de los Estados miembros a la Comunidad en áreas estrictamente limitadas. La Comunidad sólo tiene los poderes que han recibido de los Tratados y no existe ningún poder más allá de ellos, de modo que, al final, se concluye que el Derecho Comunitario concierne a poderes residuales de soberanía y esa soberanía existe en algún otro lugar más, lo que finalmente conduce al pueblo de cada Estado miembro como titular del poder soberano con fines ilimitados. A las segundas teorías se les puede objetar que el principio de competencia no sirve para resolver las principales cuestiones, a saber, ¿quién define las competencias? En definitiva, llegamos al Poder Constituyente, esto es, siempre tiene que haber un autor del ordenamiento originario. Cuestión distinta es que se abra el debate en la actualidad de qué ordenamiento ha de ser el originario: ¿el de los Estados?, ¿el de la Unión Europea? Cfr. en este sentido crítico, OBRADOVIC, D., "Community Law and the doctrine of divisible sovereignty", Legal Issues of European Integration, 1993-1, págs. 8-20; DE WITTE, B., "Sovereignty and European Integration: The Weight of Legal Tradition", en SLAUGHTER, A.-M., Y STONE SWEET, A., y otros (eds.), The European Courts \& National Courts. Doctrine and Jurisprudence, Oxford, págs. 277-304; LóPEZ CASTILLO, A., Constitución e integración, Madrid, 1996, págs. 149 y ss.; LóPEZ BASAGUREN, A., "¿Réquiem por la Constitución? El ordenamiento constitucional en la integración comunitaria", Civitas Europa, n. ${ }^{\circ} 2,1999$, págs. 7-30.

16 En este contexto, se procede a hacer frente a la nueva situación a través de adaptaciones sucesivas dentro del respeto de la base de la soberanía estatal tal y como retiene la Teoria Constitucional moderna. Se considera posible ceder el ejercicio efectivo de competencias soberanas a la nueva entidad creada, pero reservándose siempre su titularidad el Estado. Del mismo modo, no se cuestiona que el ejercicio de estas facultades pueda retornar a las instituciones estatales. Por lo tanto, se admite la limitación del ejercicio de competencias estatales en beneficio de instituciones supranacionales que se tiene que articular sobre las bases constitucionales de los Estados comunitarios, apareciendo en sus Constituciones previsiones expresas $y$ específicas que contemplan tal posibilidad, materializándose una nueva modalidad de apertura estatal que suele ser denominada uintegración supranacional". Cfr., por todos, PÉREZ TREMPS, P., Constitución Española y Comunidad Europea, Madrid, 1994, págs. 35 y ss. 


\section{III. "FORMA ESTATAL", "CONSTITUCIÓN" $Y$ «REFORMA CONSTITUCIONAL» EN EL PROCESO INTEGRADOR EUROPEO}

Para profundizar sobre el estado actual de estas cuestiones en la realidad consideramos que se ha de enfocar el estudio de la integración europea partiendo de las diferencias y analogías entre la Confederación, el Estado Constitucional y el Estado federal, por entender que la pretensión que anima la construcción europea se basa en premisas pacíficas y consensuadas, desde la lógica democrática, y mediante técnicas típicamente federales ${ }^{17}$. Desde esta perspectiva, se han de analizar comparativamente: la naturaleza jurídica del vínculo sobre el que se cimienta la unión, el procedimiento y significado de su reforma, y la eficacia jurídica de las normas que emanan de sus órganos. Para ello, creemos imprescindible realizar con carácter previo un acercamiento histórico al proceso integrador europeo, por cuanto demuestra las reticencias y proporciona la clave de los problemas que perduran hoy para fraguar una Europa unida. En el mismo, se observa cómo desde el principio la noción de soberanía estatal no encuentra fácil acomodo en la nueva estructura, lo cual se pone de manifiesto en todos los debates, avances y retrocesos de la integración.

17 Cfr. en este sentido, LA PÉRgola, A., «ll. La Confederación», en el vol. Los nuevos senderos del federalismo, Madrid, 1994, pág. 130, pág. 143, págs. 169-173; RuIPÉrez, J., La "Constitución Europea» y la..., op. cit., págs. 26-27. Por otra parte, como se sabe, en sentido amplio, el federalismo significa, de la mano de C. J. FriEDRICH, Gobierno Constitucional y Democracia, Madrid, 1975, pág. 386, que una serie de organizaciones políticas distintas, los Estados, "entran en tratos para adoptar soluciones conjuntas y decisiones comunes". Vid., en la misma línea, LEJEUNE, Y., "L'idée contemporaine de confédération en Europe: quelques enseignements tirés de l'expérience de l'Union Européenne", en VV.AA., Le concept contemporain de Confédération, Strasbourg, 1995, pág. 123; BURGESS, M., "Federalism and Federation: a Reappraisal", en Burgess, M., y GAGNON, A. G. (ed.), Comparative Federalisme and Federation. Competing traditions and future directions, New York, 1993, págs. 3-14, quien señala que el federalismo político en un sentido abierto engloba a organizaciones internacionales que presentan características federales presentes en distintos grados tanto en todos los Estados federales como en alguna Confederación. $Y$ es que el federalismo así entendido abarca diferentes manifestaciones y modelos, pudiéndose distinguir: federalismo, como idea que busca dar respuesta a la tensión entre unidad y diversidad a través de múltiples técnicas; y federación, que constituye un sistema político descentralizado con un gobierno constitucional total sobre la base de la voluntariedad, y que entraña una forma especifica de organización. Por lo tanto, concluye que existen ideas y principios federales que no siempre conducen a una Federación en el sentido expuesto, pero que son nuevas formas de unión federal, como el caso de la Comunidad Europea actual. 
Seguidamente se ha de analizar la evolución del concepto de Constitución, desde su primera manifestación como Constitución racional normativa ${ }^{18}$, y en el tránsito del primigenio Estado liberal al Estado social y democrático de Derecho ${ }^{19}$, como fórmula común a todos los ordenamientos constitucionales de los Estados miembros de la Unión Europea. La idea de Poder Constituyente ${ }^{20}$ se revela así en

18 Cfr. García Pelayo, M., Derecho constitucional comparado, 1.. ed., 3." reimpr., Madrid, 1993, págs. 34-35, quien define tal concepto como aquél que "concibe la Constitución como un complejo normativo establecido de una sola vez y en el que de una manera total, exhaustiva y sistemática se establecen las funciones fundamentales del Estado y se regulan los órganos, el ámbito de sus competencias y las relaciones entre ellos. La Constitución es, pues, un sistema de normas". Se entiende que la Constitución es, a la vez, la creadora del orden y la expresión de un orden, ya que la razón es capaz de disolver todo lo que es meramente fáctico para hacer surgir de las partes una estructura articulada como un verdadero sistema. Cfr. Hesse, K., «Concepto y cualidad de la Constitución, en Escritos de Derecho constitucional, 2. ${ }^{a}$ ed., Madrid., 1992, págs. 1-30, en particular, respecto a la importancia de la forma escrita en la Constitución, págs. 21-23; Pérez SerRano, N., Tratado de Derecho..., op. cit., págs. 499 y ss.; LuCAs Verdú, P., Curso de Derecho Político, vol. I: Introducción: Concepto, método, escuelas. Vertiente histórica del Derecho Político. El Derecho Constitucional en el marco del Derecho Político, 2." ed, 1. reimpr., Madrid, 1989, págs. 402 y ss., y vol. Il., op. cit., págs. 403-404, 416420; Ídem, "La Constitución en la encrucijada (palingenesia iuris politici)", Pensamiento Constitucional, $n .^{\circ} 4$, págs. 86 y ss.

19 Cfr. respecto a las transformaciones del Estado Constitucional, DE VEGA, P., "En torno al concepto político...", cit. págs. 714 y ss.; SCHNEIDER H.-P., "La Constitución. Función y estructura", en el vol. Democracia y Constitución, Madrid, 1991, págs. 35-52; RuIPÉREZ, J., La "Constitución Europea”, y la..., op. cit., págs. 80-84, págs. 97-98, indicando cómo las Constituciones se acomodan a las nuevas realidades a través de su profundización en el carácter de norma abierta, las transformaciones en las Declaraciones de Derechos que aumentan su número y su contenido, y su carácter de normas directamente vinculantes para los poderes públicos. Por otra parte, observa cómo perdura el principio liberal de la división de poderes aunque entendido como posibilidad de la existencia de varios partidos que puedan llegar al poder. Sobre la problemática de la Constitución en tanto norma inacabada, cfr., por todos, HelleR, H., Teoría del..., op. cit., pág. 286; Hesse, K., "Concepto $y$ cualidad de...", cit., págs. 17-22. Respecto a los cambios en las declaraciones de derechos, cfr. BATTAGLIA, F., "Los derechos fundamentales del hombre, del ciudadano y del trabajador. Esencia, evolución, perspectivas futuras", en el vol. Estudios de Teoría del Estado, Madrid, 1966, págs. 157-174; Pérez SerRano, N., "La evolución de las Declaraciones de Derechos", en Escritos de Derecho Político, Madrid, 1984, vol. I, págs. 452-530.

20 Sobre las características del Poder Constituyente además de DE VEGA, P., La reforma constitucional y..., op. cit., págs. 24-37, cfr. LuCAS VERDÚ, P., Curso de..., vol. II, op. cit., págs. 583-584; Pérez RoYo, J., La reforma de la Constitución, Madrid, 1987; Beaud, O., La puissance..., op. cit., págs. 203 y ss.; Vanossı, J. R. A., Teoría 
toda su trascendencia, pues deviene en mecanismo legitimador del poder soberano del Estado democrático. De donde se sigue lo esencial de la noción de Pueblo, que, en cuanto titular del Poder Constituyente ejercerá la suprema potestas jurídica y política que plasmará en su Constitución ${ }^{21}$.

Examen que ha de ser completado con el estudio de la naturaleza del sustrato de las Confederaciones históricas ${ }^{22}$, del que se dedu-

constitucional, vol. I: Teoría constituyente. Poder constituyente fundacional; revolucionario; reformador, Buenos Aires, 1975; Pérez Serrano. N., «El Poder Constituyente" (1947), en el vol. I de Escritos de Derecho Político, Madrid, 1984, págs. 107-144.

21 Cfr., por todos, DE VEGA, P., La reforma constitucional y..., op. cit., pág. 40, señalando que el Estado Constitucional se basa en el principio político democrático y en el principio jurídico de supremacía constitucional. Conforme al primero se entiende que corresponde al pueblo, como titular de la soberanía, el ejercicio del Poder Constituyente. Según el segundo, se considera la Constitución como lex superior, que obliga por igual a gobernantes y gobernados.

22 Cfr. García Pelayo, M., Derecho constitucional..., op. cit., pág. 205, quien define la Confederación como "una vinculación entre Estados, creada por un pacto internacional, con intención de perpetuidad, que da lugar a un poder que se ejerce sobre los Estados miembros y no, de modo inmediato, sobre los individuos". En realidad la caracterización de la Confederación se ha realizado a partir de la contraposición con el Estado federal de los modelos históricos que han existido: Confederación de las trece antiguas Colonias americanas creada por los «Articles of Confederation" en 1777 hasta la aprobación de la Constitución federal norteamericana en 1789; la Confederación Helvética de 1803 a 1848; y la situación de los Länder alemanes hasta la Constitución de 1871. Cfr. sobre sus principales etapas y características, BORGEAUD, Ch., Établissement et revisión des Constitutions en Amérique et en Europe, París, 1893, págs. 57-77, págs. 157-164, págs. 309-357; García Pelayo, M., Derecho constitucional..., op. cit., págs. 209-214, págs. 325-337, págs. 521-533; AUBERT, J.-F., "L'évolution historique des conféderations", en Le concept contemporain de Confédération, Strasbourg, 1995, págs.17-39. Se observa que suelen surgir como paso previo a la formación de un Estado Federal, anudando unas relaciones entre soberanos mediante Tratados de Derecho Internacional, que puede llegar a la renuncia posterior de su soberanía originándose entonces la creación de un nuevo Estado, propiamente federal. Otras veces este proceso fracasa y la Confederación se deshace. Cfr., en este sentido, RuIPÉREz, J., "Consideracións xerais sobre a soberanía e o federalismo na Constitución española de 1978", Revista galega de Administración Pública, n. 21, 1999, pág. 233. Por su parte, LEJEUNE, Y., "L'idée contemporaine de confédération...", cit., págs. 124-129, da cuenta de que entre la doctrina existe unanimidad en considerar que la Confederación se rige por normas de Derecho Internacional asi como el propósito de los Estados de permanecer como tales y, por lo tanto, de reservarse la última palabra. Por contra, observa como nunca ha habido acuerdo respecto a si poseen personalidad jurídica internacional y sobre la naturaleza indirecta o no de la relación entre los individuos y la Confederación. 
$\mathrm{ce}^{23}$ que, entre los rasgos que más diferencian a la Unión Europea de éstas, se encuentran: la centralización existente en la Unión Europea, con órganos propios e independientes, dotados de competencias efectivas, de los cuales emana un ordenamiento jurídico característico que origina una uniformidad normativa sobre la totalidad de los ciudadanos ausente en las Confederaciones que han existido. Por otra parte, entre sus notas comunes destacan su base contractual, esto es, su origen mediante un Tratado Internacional consensuado entre Estados soberanos que siguen siéndolo; la persistencia de sistemas de adopción de decisiones por unanimidad, el predominio del órgano intergubernamental y el principio de competencias de atribución.

Respecto el Estado federal, no hay duda de que es un Estado constitucional que descansa en la Constitución que emana del Poder Constituyente del Pueblo federal ${ }^{24}$. Constitución que procede a repar-

23 Cfr. VV.AA., Le concept contemporain de Confédération, Strasbourg, 1995, en especial, STEPHANOU, C., "L'Union Européenne et les analogies fédérale et confédérale», págs. 153-157. Definiendo el orden confederal como orden se soberanías coordinadas frente al federal como orden de soberanías integradas, vid. en el mismo MALINVERNI, G., "Les notions classiques de Confédération et d'État fédéral", pág. 42. Respecto a la polémica en torno a la personalidad jurídica internacional de la Confederación, vid. LEJEUNE, Y., "L'idée contemporaine de confédération...", cit., págs. 130-132, quien observa como existe acuerdo en reconocer que se trataría en su caso de una personalidad limitada que no hace desaparecer la de los Estados. También la mayoría sostiene el derecho a dejar la Confederación, vid., LA Pérgola, A., "ll. La Confederación", cit., págs. 138-142, ya que se trataría de una resolución del vínculo pacticio entre soberanos del Tratado constitutivo de la Confederación. Resaltando el carácter de competencias de atribución de la Confederación, vid., por todos, FORSYTH, M., "Vers un concept nouveau de la Confédération", en VV.AA., Le concept contemporain de Confédération, Strasbourg, 1995, pág. 69. Sobre la unanimidad para las decisiones más importantes, cfr. LA PÉRGOLA, A., "ll. La Confederación", cit., págs. 118-119; FORSYTH, M., "Vers un concept nouveau de la...", cit, pág. 68. En torno a la necesaria interposición estatal para la aplicabilidad de las normas de la Confederación, cfr. CARRÉ OE MALBERG, R., Teoría general del Estado, 2." ed., Méjico, 1998, pág. 103; LA PérGOLA, A., "ll. La Confederación", cit., págs. 126-133, págs. 167-169; RuIPÉREZ, J., La "Constitución Europea» y la..., op. cit., págs. 138-139. En sentido contrario, vid. LE FUR, L., État, État Fédéral et Confédération d'États, París, 1896, pág. 723.

24 Como señala Ruipérez, J., «Principio democrático y federalismo...", cit., págs. 539-547, basta observar el nacimiento de los Estados Federales para comprobar que la idea del constitucionalismo moderno se encuentra en su formación y creación. En norteamérica la articulación consciente de la idea de soberanía popular se efectuará por J. WILSON, quien en la Convención de Filadelfia afirmará que, "en todos los gobiernos, cualquiera que sea su forma e independientemente de como esté constituido, tiene que haber un poder por encima del cual no hay otro y que es llamado, en consecuencia, absoluto, supremo, incontrolable. La única 
tir las competencias ${ }^{25}$ entre los órganos centrales y los de las colectividades miembros que le es inherente, garantizando a través de la riguidez constitucional y mediante la reserva de un papel sustancial a los Estados federados en su reforma la subsistencia de su autonomía ${ }^{26}$,

cuestión es la siguiente: ¿dónde reside ese poder?". $Y$ concluirá que ese poder supremo "reside en el pueblo como la fuente de todo gobierno". De este modo, se entiende que uúnicamente el pueblo puede distribuir una parte del poder al circulo más contraído de los llamados gobiernos estatales y suministrar otra parte al gobierno de los Estados Unidos". Las citas se toman de Pérez RoYo, J., Curso de Derecho Constitucional, 3." ed., Madrid, 1996, pág. 681. El proceso de aprobación de la Constitución norteamericana seguirá tal esquema. Así, el proyecto elaborado por la Convención de Filadelfia fue aprobado y ratificado de forma distinta a la que se preveía en los Artículos de la Confederación que exigían aprobación del Congreso de.los Estados Unidos seguida de ratificación de las legislaturas de todos los Estados. Aunque en principio se pretendía modificar la Confederación, el resultado sobrepasó con mucho este propósito. Hoy sigue siendo cierto que, lo primero que destaca en cualquier Estado federal es que hay una Constitución Federal. La propia existencia jurídica del Estado Federal se refleja en una Constitución, en sentido jurídico-político, y no en un pacto internacional.

25 Sobre la importancia de que se fije tal distribución de competencias en la Constitución federal, cfr., entre otros, BuRdeAU, G., Traité de Science Politique, tomo II: L'État, 2. a ed., revisada y aumentada, París, 1967, pág. 513; LOEWENSTEIN, K., Teoría de la Constitución, 2. ed., 1. ${ }^{\mathrm{a}}$ reimpr., Barcelona, 1982, pág. 356; GARCiA PELAYo, M., Derecho constitucional..., op. cit., pág. 234; LuCAS Verdú, P., Curso de..., vol. II, op. cit., págs. 364-365; DuRAND, Ch., "El Estado federal en el Derecho positivo", en Berger, G., y Chevallier, J. J., y otros, Federalismo y federalismo europeo, Madrid, 1965, pág. 183. La razón se encuentra, como observa Ruipérez, J., Formación y determinación de las Comunidades Autónomas en el ordenamiento constitucional español, 2." ed., Madrid, 1991, pág. 44, en que tanto la organización politica central como las de las colectividades miembros "están interesadas en mantener $y$, si fuera posible, ampliar su prespectivo ámbito de poder". Por ello, la distribución de competencias sólo será efectiva cuando se establezca por una Constitución escrita y rígida que, en cuanto Norma Suprema, se imponga y obligue por igual a las autoridades centrales y a las regionales.

26 Cfr. LA Pérgola, A., Residui "contrattualistici" e struttura federale nell'ordinamento degli Stati Uni, Milano, 1969, págs. 192-193, manifestando que no existen dudas de que el principio de rigidez constitucional obtuvo su primera formulación en íntima conexión con el fenómeno del Estado federal. En el mismo sentido e incidiendo sobre la importancia de la necesaria participación de las colectividades miembros en el proceso de reforma de la Constitución federal, cfr. DURAND, Ch., "El Estado federal en...", cit., págs. 204-205. Por otra parte, esta particularidad se considera por un importante sector doctrinal como uno de los elementos más relevantes para definir un Estado como federal y que permiten contraponerlo al Estado unitario y a la Confederación. Así, cfr. BuRdeAU, G., Traité de Science..., op. cit., tomo II, pág. 492; Burgess, J. W., Ciencia Política y Derecho Constitucional comparado, vol. I: Soberanía y libertad, Madrid, 1922, págs. 174-175; CARRÉ DE MALBERG, R., Teoría general del Estado, 2." ed., op. cit., págs. 121-122; FrIEDRICH, C.-J., El hom. 
al tiempo que configura una estructura especifica de relaciones jurídicas $^{27}$ que sintetizan la dialéctica entre unidad y diversidad que les es propia constituyéndose así un sistema coherente y bien articulado.

Por contra, en la Unión Europea no existe una auténtica Constitución Europea que se corresponda con el significado jurídico-político propio de tal concepto ${ }^{28}$. La razón fundamental se encuentra en que

bre y el gobierno. Una teoría empírica de la política, Madrid, 1968, pág. 637; LOEWENSTEIN, K., Teoría de la..., op. cit., págs. 182-183; WHEARE, C., Federal Government, 3." ed., London/New York/Toronto, 1953, pág. 57; RuiPÉREZ, J., Formación y determinación..., op. cit., págs. 46-47; Ídem, La protección constitucional de la autonomía, Madrid, 1994, págs. 75-118.

27 Tales relaciones jurídicas características del Estado federal son, siguiendo a García Pelayo, M., Derecho constitucional..., op. cit., págs. 231 y ss., las de coordinación, supra y subordinación, e inordinación, las cuales se condicionan y complementan recíprocamente en la unidad dialéctica que es el Estado federal que busca el equilibrio entre la necesaria unidad estatal y el respeto a la diferencia y a una autonomía suficiente de los Estados federados. Y es que el principal problema del Estado federal es lograr conjugar los principios unificadores -la existencia de la Constitución federal y de la ciudadanía federal, así como la homogeneidad político constitucional, al tiempo que le es propio la titularidad única del poder en el pueblo-y los diferenciadores o particularizadores -entre otros, la existencia política de las unidades territoriales que se integran en el Estado Federal con voluntad política autónoma, que se manifiesta en el poder legislativo propio y en una autonomía económica que lo hace real-. Por lo tanto, el Estado Federal ha de armonizar la autonomía y la participación, y lo hace a través de fórmulas jurídicas que se establecen en la Constitución Federal.

28 A tal conclusión se llega tras analizar el sentido y los límites del concepto de Constitución aplicado a la realidad jurídico-política de la integración en su actual estadio de desarrollo. Análisis que ha de efectuarse desde un triple orden de consideraciones: Por el uso del término en el proceso comunitario europeo que asimila los Tratados constitutivos a la Constitución de la Comunidad. En segundo lugar, por los proyectos que ha habido de adoptar la fórmula de una Constitución. $Y$, por último, porque discernir esta cuestión resulta imprescindible para un cabal entendimiento de la verdadera naturaleza del fenómeno comunitario y su incidencia sobre el Estado Constitucional. En el fondo, la cuestión que se plantea es si la creciente e innegable influencia e interacción que desarrollan las Comunidades Europeas sobre las Constituciones nacionales puede llegar hasta el extremo de cuestionar la exclusividad constitucional de los Estados. Cfr. Constantinesco, V., "¿Hacia la emergencia de un derecho constitucional europeo?", Cuadernos Constitucionales de la Cátedra Fadrique Furió Ceriol, n. ${ }^{\circ} 8,1994$, pág. 9. Especial relieve presenta la caracterización del Derecho comunitario realizada por el Tribunal de las Comunidades como ordenamiento específico y autónomo, tanto frente al Derecho Internacional como frente a los ordenamientos estatales, constituyendo los Tratados la "Constitución" de la Unión, imponiendo el ordenamiento comunitario la aplicabilidad de sus normas en aquellos ámbitos competenciales propios pero sucediendo que el TJCE termina regulando las propias relaciones entre ordena- 
no existe un Pueblo Europeo unitario que como tal pueda recabar actuar como Poder Constituyente para aprobar el acto fundamental que constituye y organiza su sistema político y que pueda por ello reclamar ser el parámetro de validez y punto de referencia último del sistema ${ }^{29}$. De este modo, frente a la omnicompetencia del Estado federal, las competencias de la Unión son de atribución ${ }^{30}$. Los instrumentos fundacionales de la nueva entidad son Tratados internacionales negociados y ratificados por los Estados soberanos ${ }^{31}$ que, como Esta-

mientos. Cfr. López Basaguren, A., «Constitución y Unión Europea: aporías en la integración comunitaria", en GARCiA HERRERA, M. A. (dir.) y otros, El constitucionalismo en la crisis del Estado social, Bilbao, 1997, pág. 306, quien entiende que "esta constitucionalización pretoriana realizada por el Tribunal Comunitario supone configurar el ordenamiento comunitario como una superconstitución frente a los ordenamientos internos, de la que los Tratados constituyen su vértice normativo" (pág. 306). En el mismo sentido, cfr. Fernández Esteban, M. a L., "La noción de constitución europea en la jurisprudencia del Tribunal de Justicia de las Comunidades Europeas", Revista Española de Derecho Constitucional, n. ${ }^{\circ} 40,1994$, págs. 275-276; LóPEz CASTILlo, A., Constitución e..., págs. 373-374; DíEZ-PICAZO, L. M. ${ }^{\circledR}$, "Reflexiones sobre la idea de Constitución Europea", Revista de Instituciones Europeas, 19932, pág. 533; RodRíguez IGLESIAS, G.C., "La Constitución de la Comunidad Europeà", Noticias de la Comunidad Económica Europea, n. ${ }^{\circ}$ 100, 1993, pág. 93; GARCíA DE ENTERRÍA, E., "El proyecto de Constitución europea», Revista Española de Derecho Constitucional, n. 45, 1995, págs. 9-29; RuIPÉREZ, J., La "Constitución Europea» $y$ la..., op. cit., passim, en particular, págs. 79 y ss.

29 Cfr., por todos, RuIPÉREZ, J. La "Constitución Europea» y la..., op. cit., págs. 79 y ss.

30 Las Comunidades o la Unión carecen de la competencia de las competencias, rigiéndose por el principio de competencias de atribución como norma general aunque existen mecanismos que sirven para ampliar sus competencias. Vid. sobre el sistema de competencias comunitario, Constantinesco, V., Compétences et pouvoirs dans les Communautés Européennes, París, 1974; Tizzano, A., "Las competencias de la Comunidad", en Treinta años de Derecho Comunitario, Luxemburgo, 1984, págs. 45-72; MARTín y Pérez de NANCLARES, J., El sistema de competencias de la Comunidad Europea, Madrid, 1997. Cfr., asimismo, DiEz-PICAZO, L. M. a , "Reflexiones sobre la idea de...", cit., pág. 551, señalando que la Comunidad adolece, en el ejercicio de sus propias competencias, de un déficit democrático normativo ya que no puede legislar de conformidad con las preferencias políticas de la mayoría por tener constreñido su campo de actuación a la consecución de unos objetivos predeterminados por los Tratados constitutivos que le marcan sus fines de una manera positiva, de modo que, no dispone propiamente de libertad de opción política. Sin embargo, en el Estado Constitucional, la Constitución supone, fundamentalmente, un límite negativo a la actividad del legislador de suerte que éste, dentro del respeto de ese marco indisponible, ha de adecuar su labor a las exigencias del principio democrático y ha de aprobar las normas que resulten de la voluntad de la mayoría en cada momento.

31 Los Tratados constitutivos son auténticos Tratados internacionales, que se han regido en cuanto a forma, procedimiento y requisitos, por los métodos pro- 
dos Constitucionales, han de respetar para ello los procedimientos y límites que las Constituciones nacionales les imponen.

También en este análisis comparativo, la referencia a la reforma manifiesta su utilidad. Se observa cómo en el Estado federal cumple una función básica de garantía de la autonomía de las entidades miembros, pero que no impide la modificabilidad del sistema cuando sea necesaria. Sin embargo, para modificar los Tratados originarios de la Unión, se requiere siempre unanimidad estatal, lo que revela su base contractual y la reserva de soberanía estatal incompatible con el auténtico significado de una Constitución ${ }^{32}$.

Ahora bien, también es cierto que la Comunidad Europea se establece sobre técnicas jurídicas propias de los Estados federales, como la primacía de su ordenamiento jurídico y su aplicabilidad inmediata y directa. No obstante, aunque la primacía que reclama el ordenamiento comunitario se predica absoluta, incluida la propia Constitución nacional ${ }^{33}$, no puede aceptarse hasta su último extremo tal concepción

pios del Derecho Internacional. Los firmantes son los Estados, que los han negociado, aprobado y ratificado conforme a sus normas constitucionales. Esta misma naturaleza presentan los Tratados que los han modificado y los Tratados de Adhesión.

32 El art. 49 del TUE regula el procedimiento general de revisión de los Tratados comunitarios. Se observa la existencia de tres fases diferenciadas y consecutivas: una propiamente comunitaria, otra de carácter diplomático, y por último, una fase nacional que se sustancia en el interior de cada uno de los Estados y de conformidad con las previsiones contenidas en sus Constituciones sobre la ratificación de los Tratados Internacionales de integración, no pudiendo entrar en vigor la modificación hasta su ratificación por todos y cada uno de los Estados. En este sentido, cfr. CAMPIS ERITJA, M., "La revisión del Tratado de la unión Europea», Gaceta jurídica de la Comunidad Europea y de la competencia, Serie D, D-24, págs. 7. 80 , quien señala cómo de la exigencia de ratificación nacional se deduce que el derecho final a la conclusión del tratado de revisión se reserva a los Estados miembros, lo que refuerza el carácter jurídico de las Comunidades Europeas en tanto que Organización Internacional. En suma, de este dato se deduce que los Estados ostentan, al menos colectivamente, el poder de decisión final sobre la revisión de los Tratados fundacionales, y que cada uno de ellos puede, individualmente, impedir cualquier modificación.

33 Este alcance absoluto de la primacía del Derecho Comunitario alcanza según el TJCE a toda norma nacional con independencia de su rango, inciuso sobre las normas contenidas en las Constituciones Nacionales, como manifiesta el Tribunal Comunitario desde su sentencia Costa c. ENEL de 1964, en la cual el TJCE ya advierte que la primacía del Derecho Comunitario sobre las normas internas no depende del rango de éstas, sino que la primacía opera sobre cualquier texto interno, anterior o posterior, "de cualquier clase que sea", con lo que se infiere la inoponibilidad de la consideración de la Constitución como Ley Superior oponible a 
sin dejar irreparablemente quebrantada la supremacía constitucional establecida al servicio de la legitimación democrática del ejercicio del poder y de sus límites, $y$, muy especialmente, al aseguramiento $y$ defensa de los derechos fundamentales y libertades públicas, que siguen encontrando el ámbito más adecuado de protección en los Estados Constitucionales nacionales ${ }^{34}$.

los mandatos de la Comunidad Europea. La justificación se encuentra, como expone el Tribunal Comunitario, en que permitir quiebras en este principio equivaldría a reconocer efectos jurídicos distintos al Derecho Comunitario en los diferentes Estados, creando discriminaciones incompatibles con la naturaleza de la Comunidad. Con posterioridad, la Alta Instancia Judicial Comunitaria, aludirá expresamente a que no puede oponerse a la primacía del Derecho Comunitario ni sigúiera la Constitución misma en su fallo Internationale Handelsgesel/schaft, de 17 de diciembre de 1970, Rec. 1970 , págs. 1125 y ss., en el cual afirmará que la norma comunitaria no puede verse oponer prescripción alguna, "cualquiera que sea" del Derecho interno, añadiendo seguidamente que "la invocación de atentados sea contra los derechos fudamentales tal como están recogidos en la Constitución, sea contra los principios de una estructura constitucional nacional, no podría afectar a la validez de un acto de la Comunidad o a su efecto sobre el territorio de los Estados". Ahora bien, también es cierto que en esta sentencia el Tribunal Comunitario afirma que "el respeto a los derechos fundamentales forma parte integrante de los principios generales del derecho cuyo respeto el Tribunal de Justicia asegura", iniciándose el reconocimiento de la garantía y protección de los derechos fundamentales en el ámbito comunitario. Cfr., al respecto, por todos, MuÑoz MaCHAdo, S., El Estado, el Derecho interno y la Comunidad Europea, Madrid, 1986, págs. 150 . 155; MAngas MaRtín, A., Derecho Comunitario europeo y derecho español, 2." ed., Madrid, 1987, págs. 141 y ss.; Rodríguez IglesiAs, G. C., "Problemas jurídicos de la adhesión española a la Comunidad Europea", en VV.AA. Cursos de Derecho Internacional de Vitoria Gasteiz 1984, Oñate, 1985, págs. 217-220.

34 Cfr. DE VEGA, P., "Jurisdicción constitucional y crisis de la Constitución", Revista de Estudios Políticos, n. ${ }^{\circ} 7,1979$, pág. 108, señalando que las ideas de libertad y democracia constituyen el soporte del Derecho Constitucional tanto de ayer como de hoy, de suerte que las Constituciones siguen representando la única vía razonable para lograr satisfacer estas ideas. Cfr., en sentido similar, RUIPÉREZ, J., La "Constitución Europea», y la..., op. cit., págs. 80-84, págs. 97-98. Así, como observa Astola MADARIAGA, J., "Derechos fundamentales y Unión Europea. La necesidad de creación de un sistema de garantías para los derechos fundamentales en la Unión Europea: un ejemplo de los peligros de su ausencian, en García Herrera, M.A. (dir.) y otros, El constitucionalismo en la crisis del Estado social, Bilbao, 1997, págs. 127-131, se precisan dos elementos básicos desde una óptica formal para poder hablar en puridad de un derecho fundamental: su tutela judicial y la vinculación efectiva del legislador a su respeto. Aplicado al ámbito comunitario se colige que en el mismo no existe un sistema de garantías específico para la protección de los derechos fundamentales pese los avances realizados. Por lo tanto, se impone la conclusión de que es el Estado Constitucional el que debe garantizarlos en la actualidad. Y ello porque como manifiesta, entre otros, P. DE VEGA, «En torno al concepto político...", cit., págs. 714-719, el Estado Constitucional es el mejor instrumento que 
Por lo tanto, ha de colegirse que hay que buscar el fundamento del ejercicio de los poderes de la Unión y de sus consecuencias jurídicas en las Constituciones nacionales. Se puede transferir el ejercicio de determinadas competencias derivadas de la Constitución a una nueva entidad con unos objetivos determinados. Consecuentemente, tales facultades se van a regir por unos procedimientos y principios distintos a los propiamente nacionales. $Y$ es que la finalidad de la cesión es el ejercicio en un nuevo marco de esas potestades para alcanzar unas finalidades que sobrepasan al Estado aislado y que se estiman ventajosas. Pero, para satisfacer el principio democrático, se requiere que el ejercicio de poder en sede supranacional siga siendo un poder legitimado popularmente, limitado, juridificado y que respete los derechos fundamentales y libertades públicas garantizados como auténticos mandatos jurídicos que vinculan a todo poder público. En suma, se ha de concluir que el ordenamiento comunitario es un ordenamiento derivado, cuya base de validez arranca en primer lugar de lo dispuesto en los Tratados constitutivos, y de manera mediata e irrenunciable en las Constituciones y en los Pueblos de los distintos Estados miembros ${ }^{35}$.

se ha inventado para hacer realidad la Democracia y la protección de los derechos del hombre.

35 Frente a esta concepción comunitarista de carácter absoluto se encuentran las lógicas reticencias nacionales a reconocer la primacía del ordenamiento comunitario sobre su Constitución en razón de su definición por antonomasia de Norma primaria y fundamental de su ordenamiento jurídico que recoge la voluntad del Poder Constituyente del Pueblo. Esto da lugar a que, aunque esté asentado en los Estados miembros el reconocimiento de la primacía comunitaria, ésta se sustenta sobre bases parcialmente distintas a las mantenidas por el Tribunal Comunitario. En efecto, la primacía del Derecho Comunitario se entiende que se asienta en lo previsto en sus propias Constituciones, que interpretativamente pueden avalar tal principio a través de sus cláusulas de integración, o sobre lo dispuesto en los Textos Fundamentales respecto a la posición del Derecho Internacional general. Se trata, por lo tanto de una aceptación de la primacia del ordenamiento comunitario muy matizada en relación con sus normas constitucionales. Cfr. Rodriguez IGLESIAS, G.C., "Tribunales constitucionales y Derecho Comunitario", en PÉREZ GONZÁLEZ, M.; SÁNCHEZ ROdRígUEZ, L. I., y otros (Comisión organizadora), Hacia un nuevo orden internacional y europeo. Homenaje al Profesor M. Díz de Velasco, Madrid, 1993, pág. 1117, quien da cuenta de cómo ninguno de los Tribunales Constitucionales de los Estados miembros ha reconocido expresamente la primacía del Derecho Comunitario sobre sus propias Constituciones. En este sentido, hay que entender los pronunciamientos de los Tribunales Constitucionales de parte de los Estados miembros y los problemas suscitados a raíz de la ratificación del Tratado constitutivo de la Unión Europea que incide en la integración política, haciéndose patentes, como indica el Profesor A. López BASAGUREN, A.., "¿Réquiem por la Cons- 
Que esto sea así no resulta incompatible con la superación del marco estatal hacia un ámbito más amplio de ejercicio de poder. En este sentido se plantea si cabe un avance sustancial mediante el establecimiento de una Constitución europea ${ }^{36}$. Esta posibilidad es incuestionable desde una perspectiva dogmática, en el bien entendido que tal decisión competería a los distintos Pueblos Europeos. De este modo, éstos, en su calidad de Poder Constituyente pueden decidir la disolución del ente estatal. Seguidamente pueden celebrar el pacto social a través del cual acuerdan vivir juntos fundiéndose en una única Comunidad. A continuación y ya como Pueblo Europeo actuarian como Poder Constituyente, único facultado para aprobar una Constitución en la que recoja la forma concreta que desea dar a su convivencia común futura asumiendo las premisas básicas de una Constitución en el nuevo ámbito ${ }^{37}$. Sin embargo, hoy por hoy no existe ese

titución? El ordenamiento constitucional en la integración comunitarian, Civitas Europa, $\mathrm{n} .{ }^{\circ} 2,1999$, págs. 17 y ss., las grandes perturbaciones que la evolución del derecho comunitario produce en los presupuestos básicos del constitucionalismo contemporáneo. De este modo, si con anterioridad al TUE se habían ido resolviendo los problemas en las relaciones entre el ordenamiento comunitario y los ordenamientos internos estatales con "una retirada de los Tribunales Constitucionales que acaban aceptando en la práctica, los presupuestos de la doctrina del juez comunitario" (pág. 17), sin embargo, a partir de entonces manifiestan que se reservan su posible intervención y esbozan la existencia de límites constitucionales al poceso de integración. En el fondo, sucede que el concepto de soberanía popular sobre el que se asienta el Estado Constitucional democrático moderno y su relación con la Teoría de la Constitución, no está superado en la Unión Europea hoy, por la razón fundamental de que es el principio medular que permite entender la legitimación popular del poder sobre la que se basa el Estado Constitucional moderno, que sigue presentándose conectado con un territorio y una población en los que despliega su autoridad última. La soberanía popular de base estatal conecta las distintas instituciones estatales con el pueblo que elige a sus componentes y los controla. Sin embargo, esa conexión imprescindible en democracia, que permite reconducir los actos de poder al pueblo, de modo que éste aparece como última y suprema autoridad, falta en la Unión Europea si no es en primer lugar a través de su conexión con lo dispuesto en las Constituciones Nacionales de sus Estados miembros.

36 Se trataría de hacer verdad el principio democrático del Pueblo europeo en la Unión, como Poder Constituyente, y como elector del órgano del que emana la ley. Estos debates ponen de relieve el proceso de entrega de soberanía por parte de los Estados miembros, y de lograrse, no cabe ninguna duda que estariamos ante la configuración de una instancia decisoria universal y última en el ámbito europeo. De ahí las reticencias más o menos explícitas estatales, cuyo ejemplo más claro ha sido el "no" danés en el primer referéndum sobre su adhesión al TUE.

37 Aplicadas estas ideas a la Unión Europea supondría que el Pueblo Europeo considerado en un sentido único y formado por la colectividad indivisa de los pueblos de los Estados miembros como soberano es el único que puede como 
Pueblo Europeo por lo que falta el presupuesto esencial para establecer una Constitución Europea ${ }^{38}$ que por razón de su procedencia pueda recabar constituir la Norma Suprema de todo el sistema.

De lo expuesto se entiende que la cuestión esencial gire en torno al modo por el cual el Pueblo se transforma en una comunidad política. El elemento determinante se encuentra en el hecho de que surja y sea capaz de imponer su reivindicación de querer constituirse en una comunidad política diferenciada capaz de organizar soberanamente su destino ${ }^{39}$. El Poder Constituyente aparece como signo de la madurez

Poder Constituyente aprobar una auténtica Constitución Europea. Y esto es así porque, como manifiesta RUIPÉREZ, J., La "Constitución Europea" y la..., op. cit., pág. 123, en un auténtico Estado Constitucional es ineludible que el documento de gobierno sea «la expresión de un Pueblo que se sabe soberano y que, por ello mismo, se entiende como el único sujeto legitimado para decidir cómo quiere ser gobernado". Y es que el principio democrático soporte del Estado Constitucional se manifiesta a través del Poder Constituyente que aprueba el Texto Constitucional para dejar paso a la soberanía de la Constitución y del Derecho.

38 Resulta evidente que en el marco de la actual Unión Europea no se ha realizado el momento del pacto social por el cual los Pueblos acuerden crear una única comunidad renunciando a su propia individualidad como Pueblos diferenciados, integrándose en una unidad política superior y única: el Pueblo de la Unión Europea, que establezca y sancione una nueva y auténtica Constitución entendida en su significado moderno y técnico. Cfr. Ruipérez, J., "Algunas cuestiones sobre el momento estatal de la integración europea: La Unión Europea como forma moderna de Confederación", en García Herrera, M. A. (dir.) y otros, El constitucionalismo en la crisis del Estado social, Bilbao, 1997, pág. 631. Por lo tanto, ha de afirmarse que la Unión Europea carece de una auténtica Constitución obra de un Poder Constituyente Europeo, y que son las Constituciones estatales las que desempeñan el papel de Grundnorm también respecto a las normas emanadas por los órganos comunitarios. Cfr., en este sentido, Ruipérez, J., La "Constitución Europea" y la..., págs. 135-151; BALAgUeR CALLEJón, F., "La constitucionalización de la Unión Europea y la articulación de los ordenamientos europeo y estatal", en GARCía Herrera, M. A. (dir.) y otros, El constitucionalismo en la crisis del Estado social, Bilbao, 1997, págs. 593-596; LOPEz BASAGUREN, A., "Constitución y Unión...", pág. 331; Ídem, "¿Réquiem...", cit., pág. 10.

39 Supone que se ha producido el hecho nacional en el sentido jellinekiano. Quiere esto decir que antes de la aprobación de la Constitución se ha celebrado el pacto social que afirma la voluntad de vivir juntos, surgiendo asi un titular unitario del Poder Constituyente, el Pueblo en su conjunto, que como tal ejercita su facultad constituyente aprobando soberanamente una Constitución que organiza y garantiza el modo concreto que desean darle a su convivencia común futura. Y para aprobar esta Constitución ya no precisan la unanimidad sino que basta una mayoría cualificada puesto que han cedido su soberanía individual al conjunto. Cfr. Jellinek, G., Teoría general..., op. cit., págs. 582 y ss.; Heller, H., La Soberania..., op. cit., págs. 166-168; DE VEGA, P., "Mundialización...", cit., pág. 28, págs. 
política de un Pueblo, de modo que el acto constitucional se configura como acto de autodeterminación de ese Pueblo.

En el momento actual, el Estado Constitucional aparece como el marco fundamental de desenvolvimiento de las distintas Comunidades políticas diferenciadas y soporte de un ordenamiento jurídico originario en cada una de ellas que es reconducible siempre en última instancia al propio Pueblo como realidad unitaria. Por ello no parece factible desgajar la Constitución ni el poder político que constituye, organiza y estructura de la Comunidad política y humana que la aprueba. En suma, el principio de la soberanía estatal, entendido como principio de unidad, indivisibilidad y omnicompetencia, del poder público propio del Estado Moderno constituye la base de su sistema jurídico. El cambio del titular de la soberanía ha cambiado el principio de legitimidad del poder pero no su consustancial unidad e indivisibilidad sobre la que se sigue basando el Estado contemporáneo.

La principal manifestación de la soberanía popular en nuestro tiempo constituye el acto de redacción y aprobación de la Constitución por el Poder Constituyente, que no puede ser otro que el Pueblo como conjunto de ciudadanos en un correcto entendimiento de la democracia. Una vez entra en vigor, constituye un requisito ineludible de la lógica del sistema constitucional que todos los poderes sean limitados habida cuenta la inevitable distinción que se produce entre gober-

53-54. Pérez Serrano, N., Tratado de Derecho..., op. cit., recoge claramente esta distinción afirmando "relacionar el Poder constituyente y su obra con la creación del Estado mediante un contrato es cosa inadmisible (...) el acto constituyente no implica pactum unionis, ni pactum subiectionis: la comunidad política existe ya; y a causa de ello es por lo que puede adoptar la decisión unitaria y suprema en que consiste la aprobación de su Código político futuro. El Poder constituyente organiza una estructura, no engendra un Estado, ni instaura por primera vez la autoridad" (pág. 462), "doctrinalmente hay que suponer la previa realidad del Estado, de la comunidad consciente, de la unidad política del pueblo, para que luego pueda establecer su organización fundamental mediante una decisión primordial y suprema. (pág. 468). Y como observa RuIPÉREZ, J., La "Constitución Europea» y la..., op. cit., pág. 111, el momento del pacto social es el que resulta fundamental para determinar la titularidad de la soberanía en el Estado Constitucional, ya que se culmina el proceso por el que ceden su parte individual de soberanía en favor de una nueva entidad superior que les engloba: el Pueblo, que como único titular de la soberanía podrá imponer su voluntad a todos los ciudadanos mediante la aprobación y sanción de la Constitución, que ha de repetar el estadio anterior de partida recogiendo y garantizando los derechos y libertades individuales frente al poder político, a través de diversos mecanismos entre los que está la separación de poderes. 
nantes y gobernados. De este modo, como observa el Profesor DE VEGA, el principio democrático del Poder Constituyente del Pueblo se convierte en el principio de la supremacía constitucional ${ }^{40}$.

Esto no supone una petrificación de la normativa de mayor rango de la Comunidad política. Desde el inicio del Constitucionalismo moderno se es consciente de que el Texto Fundamental ha de ser capaz de asumir dentro de sus prescripciones los cambios que la sociedad a la que va dirigida y regula demanda. Aparece el poder de reforma constitucional que se configura como constituyente-constituido ${ }^{41}$.

40 Cfr. De VEGA, P., La reforma constitucional y..., op. cit., págs. 34-37, pág. 40, señalando que corresponde al pueblo, titular del Poder Constituyente soberano, elaborar y aprobar la Constitución. Sin embargo, como el poder soberano es absoluto y total, y de lo que se trataba era de limitar el poder, desde los inicios del Estado Constitucional está ínsita la idea de que una vez aprobada la Constitución, el Poder Constituyente debía desaparecer. De suerte que el único medio de lograr que se respetase la voluntad popular recogida en el Texto Fundamental, habida cuenta de la distinción gobernantes-gobernados, sujetando a los primeros a límites, era establecer la rigidez constitucional al tiempo que algún sistema de justicia constitucional.

41 La reforma constitucional aparece para solventar el problema de cómo lograr la adecuación entre el complejo normativo bajo el que se presenta un Texto Constitucional, que se corresponde con un acuerdo producido en unas determinadas circunstancias históricas y políticas, con el dinamismo propio de la vida estatal, garantizando así el carácter auténticamente normativo de la Constitución. El mismo sentido tiene la rigidez constitucional, cuyo fin es proteger la voluntad soberana del Poder Constituyente recogida en el Texto Fundamental frente a las posibles modificaciones que, en todo caso, habrán de realizarse de manera formal y solemne y respetando los procesos formales de revisión, agravados respecto a la aprobación de la legislación ordinaria, que aparecen dispuestos en la propia Constitución. En este sentido, la dificultad de enmienda constituye, como apunta FINER, H., Teoría y práctica del gobierno moderno, Madrid, 1964, pág. 164, un mecanismo de defensa de la Constitución que permite adecuar la realidad normativa con la realidad política, evitando la obsolescencia del Código Fundamental. Esta problemática constituye un tema añejo y básico de la Teoría constitucional, por tratarse de una materia que refleja el carácter singular de la Constitución como documento político y norma jurídica, a la vez que su conexión con el principio democrático. Se observa que la rigidez constitucional aparece como un elemento sustancial de la definición de la Constitución, $y$ ha de ser entendido como «la previsión en la propia Constitución de un procedimiento para su reforma que sea distinto y más difícil que el establecido por ella para la sanción y modificación de las leyes ordinarias". Cfr. BISCARETTI DI RuffIA, P., Derecho Constitucional, 3." ed., Madrid, 1987, pág. 183. (La cursiva en el texto). Asimismo se puede definir la reforma constitucional con J. RUIPÉREZ, "Algunas consideraciones sobre la reforma constitucional", Revista de Estudios Politicos, n. ${ }^{\circ} 75,1992$, pág. 239 , "como aquella operación normativa tendente a modificar, parcial o totalmente, una Constitución a través de órganos especiales, o procedimientos diversos de los establecidos para la legisla- 
Constituyente en la medida en que puede proceder a retocar los contenidos constitucionales, pero constituido porque en la operación de reforma es un poder también sometido a límites, formales y materiales. Los primeros se contraen al respeto de las propias normas constitucionales que disciplinan el iter reformador ${ }^{42}$. Los segundos, los límites materiales ${ }^{43}$, se identifican con los principios basilares del

ción ordinaria, y que, en tanto en cuanto que por ella se colman lagunas o se complementan y derogan determinados preceptos, producirá siempre una alteración, expresa o tácita, del documento constitucional". En el mismo sentido, cfr., SMEND, R., "Constitución y Derecho Constitucional", Madrid, 1985, págs, 129-133; LOEWENSTEIN, K., Teoría de la..., op. cit., pág. 199; DE VEGA, P., La reforma constitucional y..., op. cit., págs. 162-163; RUIPÉREz, J., "Una cuestión actual en la discusión política española: La Constitución española y las propuestas nacionalistas, o de los lími-tes de la mutación y la reforma constitucional como instrumentos para el cambio político", Civitas Europa, n.² 2, 1999, pág. 146.

42 Cfr., entre otros, JellineK, G., Reforma y mutación de la Constitución, Madrid, 1991, pág. 15; Carré De Malberg, R., Teoría General del Estado, 2. a ed., op. cit., pág. 1173; SchmitT, C., Teoría de la Constitución, Madrid, 1992, pág. 115.

43 Tales límites establecen contenidos constitucionales indisponibles para el poder de reforma, pudiendo estar previstos expresamente en el texto Constitucional, o inferirse indirectamente por no estar expresamente recogidos en la Constitución. No existe acuerdo en torno a la admisibilidad y validez de los límites sustantivos, constituyendo éste uno de los temas más polémicos del Derecho Constitucional. Se diferencian dos posturas que aparecen condicionadas por la posición de la que se parta relativa al propio concepto de Constitución, a la naturaleza del poder de reforma y su relación con el Poder Constituyente originario y los poderes constituidos, al entendimiento de las funciones de la reforma constitucional y, especialmente, al sentido y conexión del cambio constitucional con el principio democrático. Así, por un lado se sostiene que siempre existen limitaciones sustanciales a la reforma constitucional, estén o no expresamente contempladas en la Constitución. En este sentido, cfr. BuRDEAU, Traité de Science Politique, tomo. Ill: Le Statut du Pouvoir dans I'État, París, 1950, págs. 247 y ss.; Friedrich, C.J., Gobierno Constitucional y Democracia..., vol. I, op. cit., págs. 295-297; MORTATI, C., Istituzionidi diritto pubblico, t. II, Padova, 1952, págs. 1241-1242; Esmein, A., y NezARD, H., Elements de Droit Constitutionnel français et comparé, vol. I: La liberté moderne: Principes et institutions, 8. ed., París, 1927, págs. 560 y ss.; SCHMIT, C., Teoria de la..., op. cit.; págs. 119 y ss.; HESSE, K., "Concepto y cualidad de...", op. cit., pág. 20; ARNOULT, G., De la révision des constitutions. Établissement et révison des constitutions françaises. Systèmes de révision des Constitutions étrangères, París, 1895, págs: 280 y ss.; BEAUD, O., La puissance..., op. cit., pág. 307 y ss.; Pérez SerRano, N., Tratado de Derecho..., op. cit., págs. 466-467; MORODO, R., "Derecho y realidad: sobre la reforma constitucional y sus límites", Revista de Ciencias Sociales, n. ${ }^{\circ} 3$, 1969, págs. 289 y ss.; DE VEGA, P., La reforma constitucional y..., op. cit., págs. 283-286; RUIPÉREZ, J., "Una cuestión nuclear para la teoría del Derecho Constitucional: sobre la reforma de la Constitución y sus funciones en el Estado Constitucional democráticon, Anuario de la Facultad de Derecho de la Universidad de la Coruña, n. ${ }^{\circ} 1,1997$, pág. 457 y págs. 479-481; LuCAS Verdú, P., Curso de..., vol. II, op. cit., págs. $590-591$ y págs. 650 y ss. 
constitucionalismo, presentes, por tanto, en cualquier Constitución ${ }^{44}$. A los que se añaden aquellas disposiciones constitucionales definitorias de la Comunidad política concreta, cuya convivencia política la Constitución regula ${ }^{45}$.

$Y$ es que los cambios radicales en los presupuestos de la convivencia política no proceden, en la correcta inteligencia del poder de reforma constitucional, de una modificación formal del texto realizada mediante la operación de reforma, sino de la actuación de un poder metajurídico, sin sujeción a formas, ni límites: el Poder Constituyente, único que puede elaborar una Constitución de nueva planta y erigir una legalidad diferente ${ }^{46}$.

Finalmente, se ha de proceder a llevar a cabo una aproximación esencialmente pragmática, basada en el estudio del impacto normativo de las distintas figuras, hasta entonces examinadas, sobre los nacionales y territorio de los Estados miembros, exponiéndose las

44 La razón se encuentra, como señala MORTATI, C., Istituzioni..., t. If, op. cit., págs. 1241-1242, en que se dirigen a proteger las ideas nucleares sobre las que se erige el propio concepto de Constitución en su sentido moderno y técnico. Son límites de caracter material y general, entre los que se encuentran, según RUIPÉREZ, J., «Una cuestión nuclear...", cit., pág. 48, el principio democrático, el reconocimiento y garantía de los derechos fundamentales y libertades públicas, la división de poderes, y la supremacía constitucional. Si mediante la reforma se infringe alguno de tales principios, se está ante un supuesto de destrucción, supresión o cambio de la Constitución en el sentido dado por SCHMITT, C., Teoría de la..., op. cit., págs. 119-122, por ser tareas que únicamente puede acometer el Poder Constituyente.

45 Serían aquellas disposiciones fundamentales de una Constitución concreta que le proporcionan su sustancia peculiar. Son límites materiales particulares de un determinado Texto Constitucional. Se trataría de las para ScHMITT, C., Teoría de la..., op. cit., pág. 120, "decisiones políticas fundamentales", o para HESSE, K., "Concepto y cualidad de...", cit., pág. 20, el "núcleo estable». Para LuCAS VERDú, P., Curso de..., vol. Il, op. cit., págs. 531-532 se trata de "la fóçnula política». El fundamento de tales límites se encuentra, como observan MorTATı, C., Istituzioni..., t. II, op. cit., pág. 1242, y DE VEGA, P., La reforma constitucional y..., op. cit., pág. 285, en que toda Constítución se identifica con un determinado régimen político $y$ entraña una fórmula política que define materialmente y legitima socialmente el ordenamiento legal. La modificación de esos valores básicos mediante la reforma implicaría la creación de un régimen político diferente y el establecimiento de un nuevo sistema constitucional, constituyendo un supuesto de supresión o cambio de la Constitución. En el mismo sentido, cfr. RUIPÉREZ, J., "Una cuestión nuclear...", cit., págs. 481-482.

24-37.

46 Cfr., por todos, DE VEGA, P., La reforma constitucional y..., op. cit., págs. 
líneas básicas de la caracterización que se ha realizado del ordenamiento jurídico comunitario, sus principales fuentes normativas y sus principios de articulación con los ordenamientos nacionales, para cuestionarse críticamente, desde la Teoría de la Constitución, si son admisibles y hasta qué punto estas consecuencias tal y como se requieren desde el prisma comunitario. Los fundamentos constitucionales de la integración, sus posibles límites, sus condiciones y con'rol, el impacto real que se produce en el seno del Estado Constitucio ıal a todos los niveles, encuentra aqui una referencia, que necesita posterior $y$ profundo tratamiento.

Nos limitaremos a destacar que los problemas que se suscitan se acentúan por la evolución del proceso integrador que ha conducido a una creciente profundización que desborda el ámbito económico e incide ya en el campo político. Entre los factores cuyo concurso ha motivado este hecho destacan, entre otros, el papel desempeñado por el Tribunal de Justicia comunitario, quien ha procedido a configurar, como se ha indicado, el Derecho comunitario como ordenamiento jurídico autónomo respecto a los nacionales, y progresivamente desvinculado de su origen internacional, que posee sus propios principios y reglas de funcionamiento cuyas pautas se establecen en los instrumentos que las constituyen, de modo que se sitúa a los Tratados originarios en el vértice del sistema comunitario. Al mismo tiempo se afirma que este ordenamiento goza de primacía absoluta ${ }^{47}$

47 Esta primacía no se recoge en los Tratados comunitarios. Ha sido el TJCE el que ha elaborado y concretado el alcance de este principio desde 1964, fundamentándola en los caracteres y exigencias inherentes al Derecho Comunitario. Se afirma que el Tratado CEE, a diferencia de los tratados ordinarios, ha creado un ordenamiento propio, autónomo del derecho interno e internacional, que se integra en los sistemas jurídicos de los Estados miembros y que se impone a sus jurisdicciones. La Comunidad está dotada de poderes efectivos que emanan de una transferencia de atribuciones de los Estados a la Comunidad y que entraña una limitación definitiva, en esas esferas delimitadas, de sus derechos soberanos en favor del orden jurídico comunitario, no pudiendo, por lo tanto, prevalecer una norma nacional posterior contraria. De otro modo, las obligaciones contraídas en los Tratados constitutivos no podrían ser incondicionales, sino solamente eventuales, frustrándose el objetivo de integración. (STJCE Costa c. ENEL 15-06-1964. FJ 30, 31). Así, esta primacía significa que en las materias competencia de las Comunidades, el Derecho Comunitario originario y derivado prevalecerá sobre cualquier norma nacional, anterior o posterior, sea ésta del rango que sea, incluso sobre las Constituciones nacionales. Este principio opera cuando entra en colisión la norma comunitaria y la estatal, correspondiendo su aplicación efectiva sobre todo al juez nacional, forma parte del acervo comunitario y los Estados miembros deben respetarlo incondicionalmente. Desde la perspectiva del Derecho Constitucional de 
en sus relaciones con los ordenamientos nacionales, es de aplicación inmediata y dispone de eficacia directa ${ }^{48}$. Tal caracterización incide en el carácter de norma suprema propia de la Constitución Nacional, ya que las relaciones interordinamentales se terminan regulando desde el sistema comunitario, imponiendo sus exigencias de integración y uniformidad ante las cuales se descartan cualquier orden de consideraciones del Derecho Constitucional interno. Esta concepción conduce a configurar el Derecho comunitario originario como una suerte de superconstitución a la que quedaría subordinada la Constitución nacional ${ }^{49}$, convirtiéndose el Tribunal comunitario en el garante último del nuevo sistema.

cada Estado no existen mayores problemas para asumir su respeto frente al Derecho originario por haber sido ratificado por los Estados conforme a sus Constituciones. No obstante, pueden presentarse problemas por el control de constitucionalidad a posteriori de los Tratados Internacionales existente en algunos países como el nuestro. La primacía del Derecho derivado es más problemática, ya que el Derecho Comunitario predica que los Tribunales Constitucionales han de abstenerse de controlar la "constitucionalidad" de los actos de Derecho derivado, por ser su parámetro de validez los Tratados constitutivos y resultar de la competencia exclusiva del TJCE el control de su validez y su interpretación. Cfr. Kovar, R., "Ordre Juridique communautaire. Primauté du droit communautaire", Europe, Juris Classeurs, n. ${ }^{\circ} 431,1991$, págs. 1-17; LouIS, J. V., L'ordre juridique..., op. cit., págs. 162-191; IsAAC, G., Manual de Dereho comunitario general, 2.. ed., Barcelona, 1993, págs. 193-212; RodRíguez IGLESIAS, G.C., "Los efectos internos del Derecho Comunitario", Documentación Administrativa, n. ${ }^{\circ}$ 201, 1984, págs. 60-63; MANGas MARTín, A., Derecho Comunitario europeo y..., op. cit., págs. 82 y ss.; BALAGUER CALLEJón, F., "La constitucionalización de la...", cit., págs. 593 y ss.; LóPEz BASAGUREN, A., "Constitución y Unión...", cit., págs. 305 y ss.

48 La aplicabilidad directa se refiere a la estructura de la norma, significando la complitud de la norma comunitaria que no necesita interposición estatal para surtir efectos en los ordenamientos internos pues su carácter es pleno y es autosuficiente respecto al ordenamiento nacional. El efecto directo se refiere a su eficacia jurídica, esto es, atiende al contenido de la norma en el sentido de que contiene derechos y obligaciones que se incorporan al patrimonio jurídico de los particulares, y que como tales podrán ser alegados ante sus Tribunales de justicia en caso de contravención. Cfr. MILLÁN MORO, L., "Aplicabilidad directa y "efecto directo", en Derecho Comunitario según la jurisprudencia del Tribunal de justicia", Revista de Instituciones Europeas, 1984-1, págs. 445-474; WINTER, J. A., "Direct applicability and direct effect: two distinct and different concepts en Community law", Commun Market Law Review, n. ${ }^{\circ} 4,1974$, págs. 425-439.

49 Cfr. al respecto, López Basaguren, A., "Constitución y Unión...", cit., pág. 305; LENAERTS, K., Le juge et la Constitution aux États-Unis d'Amerique et dans l'ordre juridique européen, Bruxelles, 1988, págs. 176-186, págs. 525-555; págs. 645 y ss. 


\section{LOS PRINCIPIOS CONSTITUCIONALES Y EL FUTURO DE LA UNIÓN EUROPEA}

Esta concepción altera los presupuestos medulares de los Estados constitucionales que son el soporte de la Unión, a saber, la consideración de la Constitución como bóveda del ordenamiento a la que quedan subordinadas ineludiblemente las restantes normas jurídicas que se aplican a sus nacionales y en su territorio. Se produce inevitablemente una contradicción entre la supremacía que reclaman las normas de mayor rango en ambos sistemas, y que se refleja en la falta de articulación completa y coherente entre el ordenamiento comunitario y los sistemas nacionales ${ }^{50}$. Esta contradicción se acentúa en la fase actual, que busca una mayor profundización en la integración, que transcienda los objetivos propios del ámbito económico para incidiŕt en la vía de la integración política, como se ha puesto de manifiesto con la firma del Tratado de la Unión Europea en $1992^{51}$ y especialmente

50 Cfr., por todos, López Basaguren, A., "Constitución y unión...", cit., pág. 306, señalando que estamos en una fase de transición caracterizada porque el Derecho Comunitario no es un ordenamiento originario, pero, al mismo tiempo, lo Derechos nacionales han perdido en parte ese carácter. En la práctica tal situación se traduce en dos lógicas antitéticas entre el principio de primacía del Derecho Comunitario y el principio de supremacía constitucional. Su coexistencia provoca una aporia imposible de solventar adecuadamente en el actual estadio de evolución. Para resolver esta contradicción habrá de producirse una mayor evolución integradora, especialmente mediante la aprobación de una auténtica Constitución europea que resolvería la mayor parte de los conflictos actuales.

51 La firma del Tratado de la Unión Europea en 1992 evidencia la ruptura del Estado tradicional soberano, con sus nacionales, con su diplomacia exterior propia y distinta, y con la frontera como límite claro. Se encuentran en este sentido: El paso hacia una ciudadanía europea común, que supone una homogeneización entre los ciudadanos de la Unión y es el presupuesto para llegar al reconocimiento de un ejercicio similar en los derechos fundamentales. El avance hacia una política exterior común. La consolidación y culminación de una Unión Monetaria, con una moneda única y un Banco Central Europeo, y sus incidencias en la conformación de una unión en las políticas de signo económico. Se pierde uno de los atributos fundamentales de la soberanía de los Estados, esto es, la capacidad de acuñar moneda propia y de llevar a cabo una política monetaria propia. Sobre el TUE, vid. Quermone, J. L., Le système politique européen: Des Communautés économiques à l'Union Européene, París, 1993; WeILER, J. H. H., Europa fin de siglo, Madrid, 1995; AldeCOA, F. (dir.), De la Comunidad Económica Europea a la Unión Europea: una visión desde Euskadi, Bilbao, 1993; MANGAS MARTíN, A., "Aspectos jurídico-institucionales de la realización de la Unión Europea", en RODRIGUEZ IGLESIAS, G. C., y LINÁÁn Nogueras, D. J. (dir.), El Derecho Comunitario europeo y su aplicación judicial, Civitas, Madrid, 1993, págs. 161 y ss.; Louls, J. V., "L'heritage communautaire et le nouveau traité sur l'Union Européennen, en PÉREZ GonZÁLEZ, M.; SÁNCHEZ ROdRi- 
en el proceso de ratificación nacional de tal Tratado, problemas que se repiten en la negociación y ratificación de cualquier Tratado de reforma de la Unión, en último lugar respecto a la ratificación del Tratado de Niza en curso ${ }^{52}$ en donde ha aparecido el problema del no irlándes en el referéndum llevado a cabo. $Y$ ni que decir tiene que se acentúa aún más en el proceso abierto actualmente para la ampliación de la Unión a los Estados del Este europeo y las siguientes reformas que se quieren efectuar ${ }^{53}$.

GUEZ, L. I., y otros (Comisión organizadora), Hacia un nuevo orden internacional y europeo. Libro homenaje al Profesor M. Diez de Velasco, Madrid, 1993, págs. 10351042. Además, vid. los números monográficos de Gaceta Jurídica de la Comunidad Europea y de la Competencia, Serie D, D-17 y D-18, 1992; Sistema, 1993, n. 114 y 115; Revista de Estudios Políticos, $n .^{\circ} 90,1995$. Vid. sobre la ciudadanía europea, BIGLINIO CAMPOS, P., "Ciudadanía europea y legitimidad democrática", Revista de Estudios Europeos, n. ${ }^{\circ} 9,1995$, págs. 3 y ss.; BlÁzouez Peinado, M. ${ }^{\circ}$ D., La Ciudadanía de la Unión, Valencia, 1998, destacando la novedad en el proceso integrador de atribuir derechos a los nacionales de los Estados miembros con independencia del ejercicio de una actividad económica. Sobre la PESC, vid. MANGAS Martín, A., en Mangas Martín, A. Y LiÑÁN Nogueras, D.J., Instituciones y Derecho de la Unión Europea, 1. ed., Madrid, 1996, pág. 45, quien señala su endeble marco jurídico que el Tratado de Amsterdam apenas varía. Sobre la Unión Económica y Monetaria, vid. PINDER, J., "The New European Federalism: The Idea and the Achievements", en BURGESS, M., y GAGNON, A. G. (ed.), Comparative Federalism and Federation. Competing traditions and future directions, New York, 1993, págs. 53 y ss., expresando el gran significado federalizador que tiene una moneda única y un Banco central.

52 El Tratado de Niza modifica sobre todo el sistema institucional comunitario que permanece prácticamente inalterado desde el origen de las Comunidades para adaptarlo a las ampliaciones que se han llevado a cabo y preparar la Unión para integrar los países del Este europeo. Cfr. sobre este Tratado, SÁENZ DE SANTAmaría, A.; Mangas Martín, A., y otros, Tratado de Niza. Análisis, comentarios $y$ texto, Madrid, 2002.

53 En efecto, la propia la CIG que aprobó el Tratado de Niza adoptó una Declaración a favor de organizar un amplio debate sobre el futuro de la Unión concebido como una primera fase de un proceso de preparación que llevará a la convocatoria de una nueva CIG en 2004 para reformar los Tratados (Declaración n. 23 anexa al Tratado). Posteriormente, el Consejo Europeo de Laeken de 14 y 15 de diciembre de 2001 adopta una declaración sobre las iniciativas para continuar el proceso, decidiendo para garantizar una amplia preparación de la próxima CIG de 2004 convocar una Convención de composición similar a la que redactó la Carta de Derechos Fundamentales de la UE que ha de abordar los temas siguientes: delimitación de competencias entre la Unión y los Estados miembros; estatuto de la Carta de Derechos Fundamentales de la UE; simplificación de los Tratados; y función de los parlamentos nacionales en la arquitectura europea. Esta Convención ha empezado sus trabajos el 1 de marzo de 2002. Destaca el hecho de que en ese mismo Consejo se plantee el camino hacia una Constitución para los ciudadanos europeos en la que se integrarían los elementos anteriores. Pero, se advierte que 
Ante esta situación se debe proseguir reflexionando sobre los límites de la integración, por entenderse que se puede estar afectando a la propia esencia de la estatalidad $y$, por ende, a los principios sobre los cuales aparecen asentados estos Estados, Constitucionales democráticos y sociales. En esta tesitura, nuevamente ha de incidirse en que el marco estatal puede ser traspasado si así lo exigen los tiempos, las nuevas necesidades, $y$, sobre todo, la propia sociedad. Sobre este postulado, se entiende que el principal problema reside en el enfrentamiento entre el arraigo de los principios basilares del constitucionalismo, que han encontrado su marco idóneo de aseguramiento en el seno de los Estados Constitucionales y que como tales resultan comunes entre los Estados constitucionales participantes en la andadura integradora, y el análisis de si éstos se respetan y aseguran en una escala distinta, la comunitaria.

En este sentido, ya se ha indicado que el primer principio medular que se encuentra cuestionado es el principio democrático del Poder Constituyente del Pueblo que regula y limita todo el ejercicio de poder público que se pueda producir y que constituye la esencia de la Teoría de la Constitución. También resulta difícil sostener que a escala comunitaria se garantice el principio liberal que sigue siendo consustancial del concepto material de Constitución: El reconocimiento y protección de los derechos fundamentales y libertades públicas en el ámbito de la Unión no resulta suficientemente asegurado. Faltan concretos y eficaces mecanismos jurídicos, empezando por la ausencia de una Declaración de esos derechos y libertades irrenunciables en sus normas primarias ${ }^{54}$. Extremo que sigue sin solucionarse pese a la Car-

hace falta definirse sobre cuáles serian sus elementos básicos, sus valores, sus derechos fundamentales y deberes de los ciudadanos, y cuáles las relaciones de los Estados miembros dentro de la Unión.

54 Para paliar esta carencia se establece el compromiso de las Comunidades y de la Unión Europea con el respeto de los derechos fundamentales a través de dos vías: institucional, sucediéndose diversas declaraciones políticas de las Instituciones comunitarias manifestando su compromiso con el respeto y protección de los derechos fundamentales y con los valores democráticos; y por el Tribunal Comunitario que asumirá una labor primordial para asegurar su respeto en el ámbito comunitario incorporándolos como principios generales del Derecho Comunitario con rango de Derecho originario, y asumiendo su justiciabilidad. Finalmente, el TUE y el Tratado de Amsterdam introducen el art. 6 del TUE, apartados 1 y 2 positivizando tal compromiso disponiéndose que serán respetados tal y como se garantizan en el CEDH de 1950, y tal y como resultan de las tradiciones comunes a los Estados miembros como principios generales del Derecho comunitario. No obstante subsiste la preocupación por el respeto de los derechos fundamentales, 
ta de los Derechos fundamentales de la Unión Europea, firmada el 7 de diciembre de 2000 dada su falta de alcance jurídico ${ }^{55}$. El mismo

originándose un vivo debate en torno a la inclusión de un catálogo de éstos en los Tratados comunitarios. Existen partidarios de tal inclusión por otorgar una protección más segura. Cfr. DíEZ-PICAZO, L. M., "¿Una Constitución sin Declaración de Derechos? (Reflexiones constitucionales sobre los derechos fundamentales en la Comunidad Europea)", en Revista Española de Derecho Constitucional, n. ${ }^{\circ} 32,1991$, págs. 135 y ss.; GoSALBO Bono, R., "Reflexiones en torno al futuro de la protección de los derechos humanos en el marco del Derecho Comunitario y del Derecho de la Unión: insuficiencias y soluciones", Revista de Derecho Comunitario Europeo, n. ${ }^{\circ} 1,1997$, págs. 59-68. Por otro lado, algunos se pronuncian en contra de tal posibilidad por las dificultades políticas y jurídicas que tal opción conllevaría debido a las diferencias constitucionales entre los Estados miembros. Cfr. MOITINHO DE ALMEtDA, J. C., "La protección de los derechos fundamentales en la jurisprudencia del Tribunal de Justicia de las Comunidades Europeas", en RodRíGUEZ IGLESIAS, G. C. y LINÁN Nogueras, D. J. (dir.), El Derecho Comunitario Europeo y su aplicación judicial, Madrid, 1993, págs. 97-132. También se plantea la adhesión de las Comunidades Europeas al Convenio Europeo de Derechos Humanos como solución para colmar las lagunas e insuficiencias del sistema de protección de derechos humanos vigente en el ámbito comunitario, aunque también existen argumentos en contra. Cfr. sobre las distintas posturas, CARRILlo SAlCedo, J. A., "La protección de los derechos humanos en las Comunidades Europeas", en GARCía DE ENTERRÍA, E., GoNZÁlez CAMPOS, J. D., y otros (dirs.), Madrid, 1986, vol. II, págs. 25 y ss.; Mangas MaRTín, A., Derecho Comunitario europeo y..., op. cit., págs. 161 y ss.; WeILER, J.H.H., "Les droits des citoyens européens", en Révue du Marché Unique Européen, 19963 , págs. 35-64. Sea de ello lo que fuere, el Tribunal Comunitario en su Dictámen $2 / 94$ de 28 de marzo de 1996, Rec. 1996, págs. 1759 y ss., ha considerado que actualmente la Comunidad no tiene competencia para esa adhesión porque tendría una envergadura constitucional. Sólo podría realizarse mediante una modificación del Tratado que atribuyese la competencia para su ratificación a la Unión. Cfr. DE AREILza CarvajAL, J. M., «El Dictamen 2/1994 del Tribunal de Justicia o cómo no abordar el espinoso asunto de las competencias comunitarias", Revista Española de Derecho Constitucional, $n .^{\circ} 47,1996$, págs. 333-345. Se observa cómo la problemática sobre la protección de los derechos humanos en el sistema comunitario persiste y dista de estar solucionada, dado que tal sistema presenta lagunas e insuficiencias, ya que se establece una protección prioritariamente jurisprudencial casuística e insuficiente para su eficacia práctica. Cfr. en sentido crítico, Gosalbo Bono, R., "Reflexiones en torno al futuro...", cit., págs. 34-46; RODRígUEZ IGLESIAS, G. C., Y VALLE GÁLVEZ, A., "El Derecho Comunitario y las relaciones entre el Tribunal de Justicia de las Comunidades Europeas, el Tribunal Europeo de Derechos humanos y los Tribunales Constitucionales nacionales", Revista de Derecho Comunitario Europeo, n. ${ }^{\circ} 2$, 1997, págs. 329-376.

55 Publicada en el DOCE . $^{\circ} \mathrm{C} 364$, de 18 de diciembre de 2000, a raíz de la Cumbre de Niza en la que los Presidentes del Consejo, del Parlamento Europeo y de la Comisión la proclaman conjunta y solemnemente. Sobre sus antecedentes y procedimiento utilizado, cfr. FIgUenuelo, A., "La protección de los Derechos Fundamentales en el marco de la Unión Europea", Anuario da Facultade de Dereito da Universidade da Coruña, $\mathrm{n} .{ }^{\circ} 5,2001$, págs. 315-342. Destaca que el principal pro- 
balance se desprende respecto el principio de separación de poderes ${ }^{56}$. Finalmente, la supremacía constitucional, como quiera que va ligada a la protección de los presupuestos anteriores, también sólo resulta predicable, en su auténtico sentido, en el ámbito constitucional estatal.

Los Tratados Constitutivos de las Comunidades y de la Unión Europea no responden a estos rasgos. Son Tratados Internacionales a los que han dado su consentimiento los Estados parte desde sus respectivos fundamentos constitucionales. El fundamento de la Unión está en las Constituciones nacionales, esto es, en la expresión de tal voluntad que el Constituyente originario, Pueblos de tales Estados, han manifestado en sus Normas Supremas. Por lo tanto, ha de concluirse que el Poder de integración es un poder limitado ${ }^{57}$. En primera medi-

blema era determinar la naturaleza jurídica de la Carta, esto es, si se iba a tratar de una declaración únicamente de valor político o sería un texto jurídico vinculante a integrar en los Tratados de la Unión. La decisión sobre esta cuestión el Consejo de Colonia que pone en marcha el proceso se la reserva para sí. En la Cumbre de Niza queda como un texto de valor político, meramente programático. Ante esta situación y las pertinentes críticas, la CIG que aprobó el Tratado de Niza en la Declaración citada $n .^{\circ} 23$ sobre el futuro de la Unión incluye en el debate que se ha abierto determinar el estatuto de la Carta de los Derechos Fundamentales de la UE. EI Consejo Europeo de Laeken de diciembre de 2001 al convocar la Convención incluye el debate respecto a si la Carta de Derechos Fundamentales de la UE debe integrarse en el Tratado básico al tiempo que se debe plantear la cuestiónde la adhesión de la CE al CEDH.

56 La doctrina mayoritaria critica el sistema de distribución de poderes existente en las Comunidades. $Y$ es que salvo el caso del poder judicial, la articulación de las funciones normativas y ejecutivas entre Consejo, Comisión y Parlamento Europeo, es compleja y difícilmente esconde la preponderancia del Consejo, órgano preponderantemente intergubernamental. Sobre todo, destacan la falta de control del Consejo por una Cámara democrática y las carencias del Parlamento Europeo en el ejercicio de las principales funciones para que se pueda hablar de un régimen propiamente parlamentario. En el fondo, nuevamente se acusan los problemas de legitimidad que plantea la construcción comunitaria. Aunque no es. cuestionable su legitimidad jurídica, no sucede lo mismo con su legitimidad democrática, ya que el principio democrático y de la soberanía popular, sin el que no es comprensible el Estado Constitucional hoy, no están presentes en la Unión Europea. $Y$ este déficit se presenta tanto en el procedimiento decisorio como en el procedimiento normativo. Cfr., por todos, Fernández Esteban, M. L., "La noción de Constitución europea...", cit, pág. 289.

57 Cfr. Alonso Garcia, E., "La incidencia de la entrada en las Comunidades Europeas en el sistema constitucional de Fuentes del Derechon, en AGUIAR DE LUOUE, L. (coord.), Implicaciones constitucionales y políticas del ingreso de España en la CEE y su incidencia en las Comunidades Autónomas, Oñati, 1986, pág. 125, págs. 148-149; Vernet I Llovet, J., "Los límites a la integración europea", Civitas europa, n. ${ }^{\circ} 3,1999$, págs. 311-342. 
da porque, para actuarlo, se han de respetar los requisitos exigidos tanto formales como procedimentales en la Constitución. En segundo lugar porque, aunque no existan límites materiales explícitos, sí existen límites implícitos.

De este modo, se entiende que las Constituciones nacionales permiten la integración y las consecuencias jurídicas que ésta entraña. Así se acepta la primacía aplicativa de las normas comunitarias en los conflictos que se producen con normas del ordenamiento nacional de rango infraconstitucional, por entender que se trata de un efecto cubierto por la propia Constitución. En este sentido, parece que el concepto de autorruptura constitucional ${ }^{58}$ permite dar adecuada justificación a la recepción del Derecho comunitario derivado, permitiendo que sea fuente de aplicación directa y preferente en el interior del Estado, con repercusiones sobre sus fuentes. Sin embargo, no se puede pretender que por la integración la Constitución devenga inaplicable al campo cada vez más amplio cubierto por la normativa comunitaria. Lo que se atribuyen son competencias derivadas de la Constitución, nunca el Poder Constituyente fundamento de tales competencias. Desde esta óptica, se entiende que no cabe considerar que la integración

58 Cfr. Pérez Royo, J, Las fuentes del Derecho, $4 .{ }^{2}$ ed., Madrid, 1988, págs. 147-166, que entiende que los Tratados del artículo 93 de la CE tienen la función de transferir a una instancia supranacional la competencia para producir Derecho que sin ninguna mediación estatal ulterior va a tener vigencia como Derecho interno, esto es, tienen una función de habilitación que origina una especial incidencia en el ordenamiento español en general y en su sistema de fuentes del Derecho en particular. Se trata de una inserción en el sistema nacional-estatal de fuentes que en ocasiones perturba o rompe la lógica interna y plantea problemas de conflicto difíciles de solventar. En sentido similar, RUIPÉREZ, J., La "Constitución Europea» y la..., op. cit., págs. 66-69, págs. 94-95, entiende que el proceso de integración europeo ha producido un quebrantamiento constitucional permitido por la Constitución, una autoruptura, que se circunscribe únicamente a que el Derecho derivado comunitario pasa a ser fuente de aplicación directa y preferente en el interior de los Esta. dos miembros, originando repercusiones sobre las fuentes del Derecho porque se puede provocar un conflicto entre fuentes internas. No obstante, señala que es desde el propio Derecho interno donde hayan de encontrarse las soluciones, ya que la Constitución es la fuente de validez del Derecho del Estado, y el ordenamiento jurídico comunitario, aunque sea un ordenamiento propio, depende en su carácter obligatorio y vinculante en última medida de los Estados miembros, de sus Constituciones nacionales que permiten y legitiman el carácter obligatorio $y$ vinculante del Derecho Comunitario. Cfr. Balaguer Callejón, F., "La constitucionalización de la...", cit., pág. 596; VERnET I LloBeT, J., "Los límites a la...., cit., pág. 322; LÓPEZ BASAGUREN, A., "Constitución y Unión...", cit., págs. 322-330; Rubıo LlORENTE, F., "La Constitución Española y el tratado de Maastricht», Revista Española de Derecho Constitucional, n. ${ }^{\circ} 36,1992$, págs. 254-255. 
constituya un mecanismo especial de reforma de la Constitución ${ }^{59}$, de manera que ampararía disposiciones comunitarias contrarias a sus mandatos hasta producir su vaciamiento. Más correcto consideramos encuadrar las consecuencias que produce el fenómeno integrador como una mutación en determinados mandatos de la Constitución, según la definición de K. HESSE, quien la considera como aquel cam-

59 Cfr. Rodriguez-ZAPATA Y Pérez, J., "Los tratados internacionales y los controles de constitucionalidad", Revista Española de Derecho Administrativo, $\mathrm{n} .^{\circ} 30$, 1981, págs. 481 y ss., quien sostiene que el artículo 93 permite una autoruptura de la rigidez constitucional, de suerte que estima admisibles Tratados que reformen parcialmente la Constitución, como los comunitarios, siempre y cuando no incidan en los supuestos comprendidos en el art. $168 \mathrm{CE}$. Tesis que recoge el Consejo de Estado español en sus Dictámenes sobre la ratificación del TUE -núm. 850/91 de 20-6-91 y núm. 421/92 de 9-4-92, Recopilación de Doctrina Legal del Consejo de Estado Año 1991, págs: 12-20, y 1992, págs. 2-10. En ambos Dictámenes considera que la Constitución puede ser reformada, además de por los procedimientos expresamente contemplados en su Título $X$, también mediante la aprobación de un Tratado Internacional cuya ratificación se autorice por Ley Orgánica y que presente la finalidad de atribuir a una instancia internacional competencias derivadas de la Constitución. Lógicamente, con esta tesis se olvida el sentido y significado del instituto de reforma de la Constitución dirigido a proteger la supremacía de la

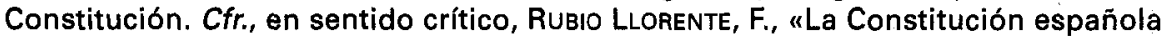
y...", cit., págs. 258-260; ARAGON, M., "La Constitución Española y el Tratado de la Unión Europea: la reforma de la Constitución", en XVI Jornadas de estudio. La Constitución Española en el ordenamiento comunitario europeo, Vol. I, Madrid, 1995, págs. 1038-1039; MuÑoz MACHADO, S., La Unión Europea y las mutaciones del Estado, Madrid, 1993, págs. 33-37; VeRnET I LlOVET, J., "Los límites a la...", cit., pág. 321. También son rechazables las tesis que sin acudir expresamente a la autoruptura sostienen que la integración europea puede constituir cauce legítimo para. reformar las Constituciones nacionales, entendiendo que el artículo $93 \mathrm{CE}$ constituye un supuesto de reforma de la Constitución a añadir a los contemplados expresamente en su Título X. Cfr., en este sentido, Mangas MARTín, A., Derecho Comunitario europeo y..., op. cit., pág. 30, págs. 128-165; GonZÁLEZ CASANOVA, J. A., y CASANOVAS Y LA Rosa, O., "Phénomène régional et intégration", en L'Espagne et les Communautés Européennes, Bruxelles, 1979; pág. 129. Sin embargo, no parece correcto por partir de una equivocada identificación entre la cesión del ejercicio de competencias derivadas de la Constitución, cubierta por el artículo 93 de la $C E, y$ reforma constitucional. Como observan PÉREZ TREMPS, P., Constitución Española y..:, op. cit., págs. 60-64; Rodríguez-VERGARA DíaZ, A., "Los límites constitucionales a la cesión de competencias a la Unión: comentario a la Declaración del Tribunal Constitucional Español sobre el Tratado de la Unión European, en el vol. I, La Constitución española en el ordenamiento comunitario europeo, XVi Jornadas de Estudio organizadas por la Dirección General del Servicio Jurídico del Estado, Madrid, 1995, págs. 923 y ss.; VERNET I LloVET, J., "Los límites a la...", cit., págs. 314 y ss.; LóPEZ CAstillo, A., Constitución e..., op. cit., págs. 216-227. Además, es contundentemente rechazada por nuestro Tribunal Constitucional en la Declaración de 1-7-1992 sobre el TUE. 
bio no formal en el Código Fundamental que «modifica, de la manera que sea, el contenido de las normas constitucionales, de modo que, la norma, conservando el mismo texto, recibe una significación diferente" 60 , advirtiendo, con el citado autor, que las posibilidades de una mutación constitucionalmente lícita terminan donde existe una contradicción literal y frontal con lo prevenido por el texto Constitucional. Cuando éste sea el caso, ha de acudirse a la reforma constitucional.

Esta exigencia se encuentra además recogida en diversos Textos Constitucionales como en el artículo 95.1 de nuestra Constitución ${ }^{61}$. No cabe disponer de la Constitución misma ${ }^{62}$. Se puede atribuir el ejercicio, que no la titularidad, de competencias determinadas y tasadas. Si esta atribución entraña contradicciones insalvables con el resto de prescripciones constitucionales sólo cabe: renunciar a ratificar el Tratado, renegociarlo, o reformar la Constitución con carácter previo a la ratificación estatal. Y esta última posibilidad es factible sin olvidar que

60 HESSE, K., "Límites de la mutación constitucional", en el vol. Escritos de

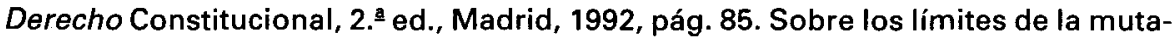
ción, cfr. del mismo autor y obra, págs. 102-103; DE VEGA, P., La reforma constitucional Y..., op. cit., págs. 179-180; LuCAs Verdú, P., Curso de Derecho Político, vol. IV: Constitución de 1978 y transformación político-social española, Madrid, 1984, págs. 158-223; RUIPÉREZ, J., "Una cuestión nuclear...", cit., págs. 476-477.

61 Además del art. $95 \mathrm{CE}$, vid el Reglamento del Congreso - art. 157-y del Senado - art. 147- sobre los requisitos para solicitar la Declaración del TC, entre los que destaca que si el requerimiento parte de alguna de las Cámaras ha de ser aprobado por el pleno por mayoría. Igualmente, el artículo 78 de la Ley Orgánica 2/1979, de 3 de octubre, del Tribunal Constitucional, que establece los requisitos, procedimiento y carácter de tal Declaración del Tribunal Constitucional.

62 Declaración del TCE de 1 de julio de 1992 (BOE 24-7-1992), FJ 4., afirmando que no caben Tratados Internacionales de ningún tipo contrarios a la Constitución, ya que el tenor y el sentido del artículo 95.1, aplicable a todo tipo de tratados, excluyen el que contradigan o excepcionen las reglas constitucionales que limitan el ejercicio de todas las competencias que la Constitución confiere, aunque el ejercicio de algunas pueda cederse según lo dispuesto en su artículo 93. Pero, los poderes públicos españoles están igualmente sujetos a la Constitución tanto cuando actúan en las relaciones supranacionales como en el ejercicio interno de sus atribuciones. Además se manifiesta que sólo cabe variar los enunciados de la Constitución mediante su reforma expresa, esto es, por los cauces del título $X$ de la CE. Cabe autorizar por Ley Orgánica, la ratificación de tratados que transfieran a organizaciones internacionales el ejercicio de competencias constitucionales, modulándose así, el ámbito de aplicación, no el enunciado, de las reglas que las han instituido y ordenado, porque es un efecto previsto por la Constitución. Pero ninguna relación guarda con la colisión textual y directa, de modo que no cabe admitir un tratado contra Constitutionem, definitivamente excluido por el artículo 95. 
el poder de reforma de la Constitución es un poder limitado. Consecuentemente, la reforma de la Norma Suprema para adecuarla a los nuevos fines susceptibles de plantearse en la integración europea, se encuentra limitada. El único que puede dar el paso decisivo es el Constituyente originario.

Tal fenómeno es difícil que se produzca en la situación actual. El alejamiento de los Pueblos de los Estados del fenómeno comunitario, la ruptura de la uniformidad que se ha producido en los fundamentos de la Unión, la propia introducción de la cooperación reforzada, la futura ampliación de socios comunitarios que acrecienta la diversidad, el sistema institucional mal redimensionado respecto a las poblaciones al que intenta ponerle solución el Tratado de Niza, los esquemas intergubernamentales en parte de los ámbitos más importantes, la necesaria unanimidad estatal para acometer cualquier reforma, la descompensación entre lo económico y lo político ${ }^{63}$, la indefinición política constante,... Todo ello muestra las dificultades del proceso, y no parece augurar que ni a corto ni a medio plazo se constituya un auténtico Estado Constitucional Europeo en el que las Constituciones nacionales aparezcan subordinadas a una presunta Constitución Europea.

Mientras tanto, cabe y es deseable proceder, conforme indica $P$. Häberle ${ }^{64}$, a dotar de mayor legitimidad democrática al conjunto del sistema a través de una actividad paralela. Por un lado, en el ámbito europeo, procurando una mayor democratización en la toma de decisiones $y$ en el proceso de creación de normas comunitarias, y asegurando el compromiso y garantía efectiva de los derechos y libertades fundamentales que, al fin y al cabo, constituyen un supuesto que está en la base de todos los Estados Constitucionales participantes. Por otra parte, resulta indispensable establecer desde las propias Constitucio-

63 Cfr. en este sentido, entre otros, URIARTE TORREALDAY, R., "La incidencia de la integración económica sobre la Constitución económica», pág. 389; y ABELLÁN, A., "La problemática del Estado de Bienestar como fenómeno internacional", págs. 201-207, ambos en García HerRera, M.A. (Dir.) y otros, El constitucionalismo en la crisis del Estado social, Bilbao, 1997, pág. 389. Cfr., asimismo, RuIPÉREZ, J., La "Constitución Europea" y la..., op. cit., pág. 32, pág. 75.

64 Cfr. HÄBERLE, P., «Programas sobre Europa en Constituciones y Proyectos constitucionales recientes. El desarrollo del «Derecho Constitucional nacional sobre Europan», en el vol. Retos actuales del Estado constitucional, Oñate, 1996, págs. 125 y ss.; "¿Existe un espacio público europeo?», Revista de Derecho Comunitario Europeo, $.^{\circ} 3,1998$, págs. 134-136. En la misma línea, cfr. RoDRíguez IGLESIAS, G.C., "Consideraciones sobre la formación de un Derecho Europeo", Gaceta Jurídica de la Comunidad Europea y de la Competencia, n. ${ }^{\circ} 200,1999$, págs. 23-25. 
nes nacionales un mayor fundamento constitucional del fenómeno integrador, lo que requiere que se establezca claramente cuáles son las competencias cuyo ejercicio es susceptible de cesión, e incluir límites sustantivos a esa transferencia.

Pero aun así, como se ha expuesto, este proceder se encuentra limitado. El Derecho tiene límites y no puede suplirse mediante una técnica la falta de voluntad política. Si el soberano es el Pueblo, es a éste al que le compete en primera y única instancia adoptar las decisiones fundamentales que le afectan. La disolución del Estado nacional en una instancia superior atenta a todos los principios sobre los que se sustentan los Estados Constitucionales que conocemos desde el punto de vista de la legalidad vigente. Por lo tanto, tal acto sólo puede ser fruto de una acción revolucionaria, de un acto del Poder Constituyente, único facultado para erigir una legalidad diferente.

Confederación de tipo moderno caracterizada por el efecto prevalente y directo de las normas jurídicas que emanan de los órganos comunes y por la amplitud de fines y su sustrato de partida democrático, consensuado y pacífico65; Organización Internacional suprana-

65 La caracterización de la Confederación moderna se debe a LA PÉRGOLA, A., "Il, La Confederación", cit., págs. 124 y ss., quien encuadra dentro de ésta a la Unión Europea en su momento actual, destacando que la forma moderna confederativa no está destinada a convertirse en un ente estatal, de modo que la soberanía seguiría en manos de los Estados, y el ordenamiento comunitario habría de respetar siempre los límites esenciales derivados de las Constituciones estatales. Además, manifiesta que es factible perfeccionar su sistema dotándolo de una mayor legitimidad democrática y de un catálogo de derechos fundamentales a través de una Constitución Confederal que ha de venir del Parlamento Europeo. RutPÉREZ, J., La “Constitución Europea” y la..., op. cit., págs. 153-168, comparte esta opinión, pero critica la propuesta del Profesor italiano de dotarla de una Constitución según la cual la actividad futura de la Unión Europea debe conjugar el principio de soberanía popular con el de la soberanía de los Estados miembros. La objeción la basa en que una vez aprobada y en vigor esa Constitución, se reconoce la condición de soberano tanto al pueblo europeo en su sentido unitario como a los pueblos respectivos de los distintos Estados miembros. Sin embargo, la soberanía es inalienable e indivisible y no cabe sostener la existencia de dos sujetos igualmente soberanos sobre un mismo territorio, ya que en tales circunstancias no existiría propiamente unidad estatal. De este modo, hay que preguntarse quién detenta realmente la soberanía en la Unión Europea bajo esa nueva Constitución: Lel pueblo europeo o los pueblos estatales? Si se estima que reside en cada uno de los pueblos de los Estados miembros, se entiende que el pacto social no se ha verificado en la Unión Europea, que es una unión confederal de Estados, y, por tanto, su norma fundamental no es una verdadera Constitución. Si se admite que el ejercicio de Poder Constituyente se ha conferido al Parlamento Europeo como repre- 
cional o de integración ${ }^{66}$; Confederación política y Federación económica ${ }^{67}$... Se observa, en suma, cómo el intento de definir este nuevo marco resulta especialemente dificultoso. Sin embargo, se hace inevitable, habida cuenta de su incidencia sobre el Estado Constitucional que, desde que se configuró como tal se presenta actualmente como

S€ ntantes de los ciudadanos europeos, ha de colegirse que se ha verificado el pac+o social, y que es ese Pueblo europeo el auténtico titular de la soberanía. En tal ' aso, la norma fundamental de la Unión sería una auténtica Constitución que constit 'ye un único Estado Constitucional de carácter federal en el que los Estados mi mbros han dejado de ser soberanos.

66 El término de Organización Supranacional lo empleó por primera vez Rosenstiel en su obra Le principe de supranationalité. Essai sur les rapports de la politique et du droit, París, 1962. Sin embargo, el problema que entraña este concepto es su ambigüedad e imprecisión jurídica, como pone de manifiesto, ConsTANTINESCO, V., Compétences et pouvoirs dans..., op. cit., págs. 46-58. Vid. un intento de conceptualización del supranacionalismo en WEILER, J. H. H., /l sistema comunitario europeo, Bologna, 1985, págs. 39-112. Resulta entonces que hay quienes estiman que es una fórmula distinta a la tradicional, ya que se basa en lograr una integración frente a una simple colaboración, por lo que existe un cambio de naturaleza, como DíEZ dE VELASCO VALLEJO, M., Instituciones de Derecho Internacional Público, 10.ed., Madrid, 1994, Vol. II, pág. 37; MEDINA, M., La Comunidad Europea y sus principios constitucionales, Madrid, 1974, págs. 105 y ss. Por contra, otros opinan que ambos supuestos tienen encaje dentro de la categoría de las Organizaciones Internacionales distinguiéndose por el grado más o menos intenso de relación entre los Estados que presenten, como DE WITTE, B., "Retour à Costa. La primauté du droit communautaire à la lumière du droit international», Révue Trimestrielle de Droit Européen, 1984, págs. 424-425.

67 En este sentido, cfr. WEILER, J. H. H., "Parlement européen, intégration européene, démocratie et légitimité", en LouIs, J. V., y WAELBROECK (dirs.), Le Parlement européen dans l'évolution institutionnelle, Bruxelles, 1988, págs. 325 y ss. Resulta interesante la tesis que expone el mismo autor en "The Community System: The Dual Character of Supranationalism", Yearbook of European Law, 1981, págs. 267 y ss., caracterizando el sistema comunitario europeo como un sistema supranacional con dos vertientes: una normativa y una decisoria. Ambas se encuentran íntimamente ligadas en una relación que no duda en calificar de esquizofrénica. $Y$ esto es así porque se ha construido una verdadera supranacionalidad normativa que supone pérdida de soberanía nacional para los Estados participantes. Pero, la contrapartida ha sido que estos Estados se muestren especialmente reticentes a perder el control de la vertiente decisoria. Todo ello provoca una fuerte contradicción dentro del desarrollo de la "Comunidad de Derecho europea", la cual se manifiesta, entre otros extremos, en la distinta situación de sus fuentes formales -comparables a las de cualquier ordenamiento democrático-, y las materiales - que no soportan la comparación con el Estado de Derecho-. De esta suerte, concluye que la Comunidad Europea presenta un doble déficit democrático, ya que la estructura ambivalente del Consejo, híbrido entre una institución comunitaria y una conferencia intergubernamental, da lugar a que no sea responsable ni ante el Parlamento Europeo ni ante los Parlamentos nacionales. 
Estado comunitario ${ }^{68}$. Su dinámica, su carácter inacabado, su originalidad, la búsqueda de su fórmula definitiva hacen especialmente difícil un intento que, no obstante, no se puede obviar, si no se quiere desconocer la realidad sobre la que se asienta la Constitución y el Derecho hoy, al tiempo que vislumbrar los riesgos propios de los nuevos tiempos para concentrarse en la defensa de aquello irrenunciable.

68 Cfr. Pérez Calvo, A., "La dimensión comunitaria...", cit., págs. 29-32; Ídem, "Las transformaciones estructurales del Estado-Nación...", cit. pág. 10. 